\title{
16. PETROGRAPHY AND DIAGENESIS OF SANDS AND SANDSTONES, DEEP SEA DRILLING PROJECT LEG 66 ${ }^{1}$
}

\author{
Cynthia M. Lopez, Department of Geological Sciences, The University of Texas at Austin, Austin, Texas
}

\begin{abstract}
Sands and sandstones from Leg 66 of the Deep Sea Drilling Project can be grouped into three general categories based upon textural and diagenetic similarities. Early Miocene upper slope sandstones from Sites 489 and 493 are cemented either by calcite or by gypsum. Calcite is volumetrically the most important cement; it occurs as a void-filling cement in foraminifer chambers, as a micritic to sparry pore-filling cement, and as a replacement mineral in framework grains. The gypsum cement has a patchy distribution and appears to have been introduced along fractures in upper slope sands.

Quaternary lower slope sands from Sites 488 and 486 are either weakly consolidated or totally unconsolidated. Framework grains in finer-grained sands are surrounded by thin, discontinuous films of chlorite and illite, which originated largely from the in situ alteration of biotite. Coarser-grained sands have thicker, more continuous clay films that consist of altered detrital biotite and of mechanically dispersed illite and chlorite. Subsequent burial diagenesis could totally obscure these differences in the origin of matrix between the finer-and coarser-grained sands.

Middle to late Miocene slope sands from Site 492 have a complicated diagenetic history. There is a pervasive network of fractures throughout the sands, yet there has been no rotation of grain fragments. Either the sands were fractured tectonically following compaction or they were fractured as a result of compaction subsequent to decementation. Interbedded shales from this site are also intensively fractured, which suggests that the possibility of tectonic fracturing is more likely.
\end{abstract}

\section{INTRODUCTION}

Sandy units are present in core recovered from the upper, mid-, and lower slope and trench floor sites along the Deep Sea Drilling Project Leg 66 transect (Figs. 1 and 2). Well-indurated sandstones, all Miocene in age, occur only in upper slope Sites 489 and 493. Lower to midslope and trench sands are poorly consolidated and coarser grained; these sands are Quaternary to probable early Pliocene in age. A total of 40 samples representative of cored intervals were selected for petrographic analysis (Table 1). This report describes the diagenetic features of these sands and interprets their diagenetic histories.

\section{ANALYTICAL METHODS}

All samples were impregnated with blue-dyed epoxy to enhance intragranular porosity and dissolution features. Three hundred points per thin section were counted to establish percentages of framework grains, matrix, cements, and porosity for consolidated samples. Identification of authigenic minerals was confirmed by X-ray diffraction of whole-rock samples.

\section{UPPER SLOPE SANDS AND SANDSTONES}

\section{Site 489}

Site 489 is located on the upper slope of the Middle America Trench off southwestern Mexico (Fig. 1). Five lithostratigraphic units are present in the 187 meters of core recovered from Holes 489 and 489A (Fig. 2): Quaternary muddy silt (Unit 1), early Miocene muddy silt and siltstone (Units 2, 3, and 4), and schist (Unit 5).

\footnotetext{
1 Initial Reports of the Deep Sea Drilling Project, Volume 66.
}

Three representative samples of calcareous sandstone beds near the base of Unit 4 were analyzed. All are laminated, calcite-cemented sandy siltstones to very fine sandstones and can be compositionally classified as plagioclase-dominant subarkose to arkose (McBride, 1963). Accessory components include biotite, hornblende, muscovite, zircon, glauconite, shell material, and organic debris. The lack of rounding and size sorting among framework grains is characteristic of a texturally submature sandstone. However, the original texture and composition of sandstones from Site 489 have been altered considerably by diagenetic reactions.

\section{Cementation History}

Three stages of intergranular cementation are distinguishable in sandstones from Site 489. The first stage involved the development of clay skins parallel to the surfaces of framework grains. The skins are surrounded by isopachous rims of fibrous iron-free calcite cement (Figs. 3 and 4). The distribution of the Stage 2 calcite cement is influenced by grain size because it is found only on grains with long diameters exceeding $0.1 \mathrm{~mm}$. The fibrous cement does not show a preference with respect to grain mineralogy. In the third stage of cementation, the remaining pore space was filled in with micritic to sparry iron-free calcite and granular pyrite. The coarsegrained nature of both calcite cements and the obscured microstructures in much of the shell material indicate that some recrystallization has occurred. Framework grains have been so extensively replaced by calcite and, to a lesser extent, by pyrite that these authigenic minerals occupy from $60 \%$ to $88 \%$ of the whole-rock volume.

Sparry iron-free calcite, ferroan calcite, and framboidal pyrite occur as chamber-filling cements in fora- 


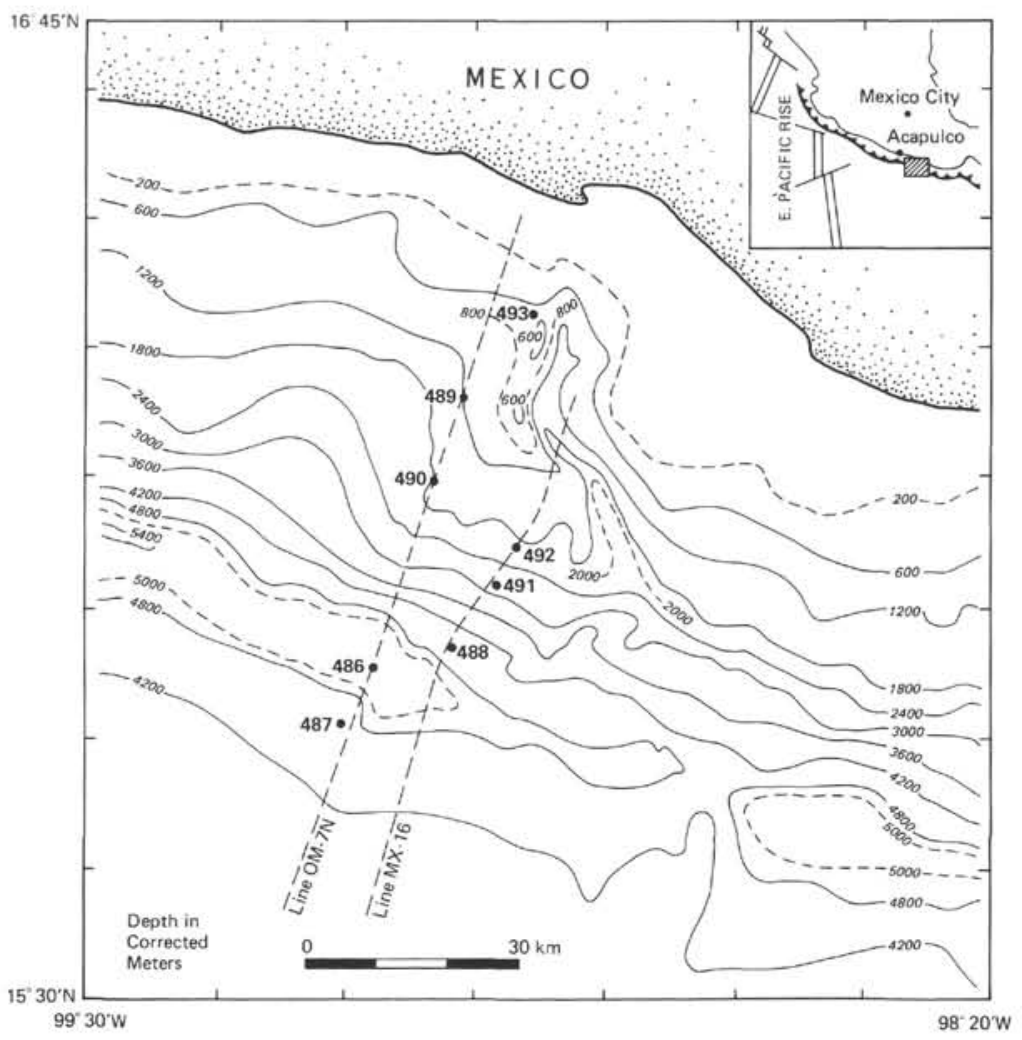

Figure 1. Location of Leg 66 sites.
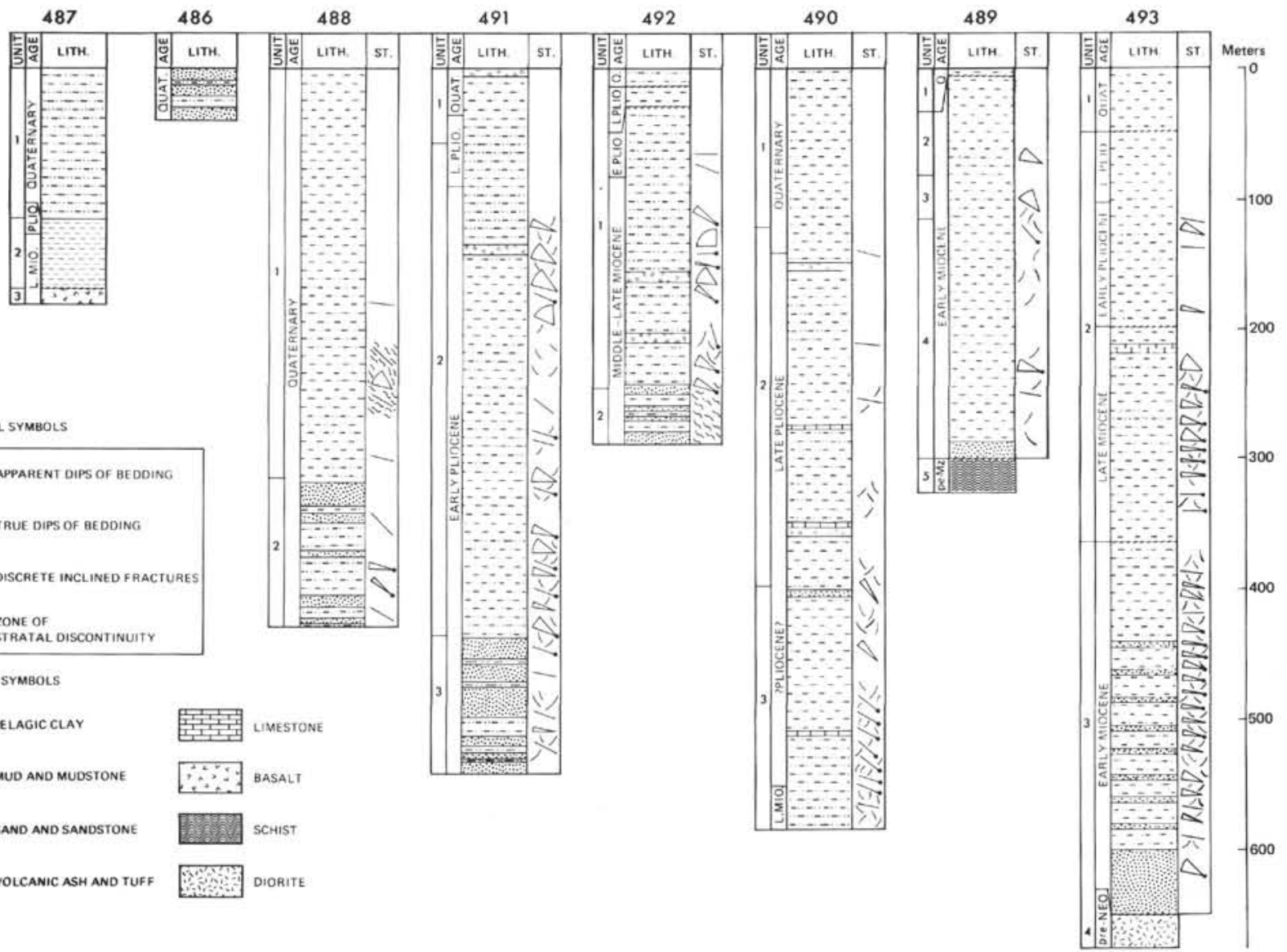

Figure 2. Simplified stratigraphic columns for Leg 66 sites. 
Table 1. Data on intervals sampled.

\begin{tabular}{|c|c|c|c|}
\hline $\begin{array}{l}\text { Hole, Water Depth, } \\
\text { and Age }\end{array}$ & $\begin{array}{l}\text { Sample } \\
\text { (interval } \\
\text { in } \mathrm{cm} \text { ) }\end{array}$ & $\begin{array}{l}\text { Depth } \\
\text { BSF (m) }\end{array}$ & Core Description \\
\hline \multirow[t]{2}{*}{$\begin{array}{l}486 \text { (trench }-120 \mathrm{~km} \\
\text { SE of Acapulco, } \\
\text { Mexico) } \\
5100 \mathrm{~m} \\
\text { mid-Pleistocene? }\end{array}$} & $\begin{array}{l}3-1,5-7 \\
3-1,99-101 \\
3-2,50-52 \\
3-4,64-66 \\
3-5,0-2 \\
3-5,98-102 \\
3-6,50-52 \\
3, C C, 0-2\end{array}$ & $\begin{array}{r}9.5 \\
10.5 \\
11.0 \\
14.6 \\
16.0 \\
17.0 \\
18.0 \\
19.0\end{array}$ & $\begin{array}{l}\text { Muddy sand, olive black, } \\
\text { fine- to medium grained, } \\
\text { locally coarse-grained, } \\
\text { structureless, soupy. }\end{array}$ \\
\hline & $\begin{array}{l}5-1,50-52 \\
5-1,99-107 \\
5-2,50-52 \\
5-2,139-141\end{array}$ & $\begin{array}{l}29.0 \\
29.5 \\
30.5 \\
31.4\end{array}$ & $\begin{array}{l}\text { Fine to medium mica- } \\
\text { ceous sand, olive gray } \\
\text { grading to medium to } \\
\text { coarse sand, medium } \\
\text { dark gray through } \\
\text { sections } 1 \text { and } 2 \text {. }\end{array}$ \\
\hline $\begin{array}{l}486 \mathrm{~A} \text { (trench }-120 \mathrm{~km} \\
\text { SE of Acapulco, } \\
\text { Mexico) } \\
5100 \mathrm{~m} \\
\text { mid-Pleistocene? }\end{array}$ & $3-1,29-31$ & 14.8 & $\begin{array}{l}\text { Fine to medium muddy } \\
\text { sand, olive gray, } \\
\text { micaceous. }\end{array}$ \\
\hline \multirow[t]{3}{*}{$\begin{array}{l}488 \text { (base of lower } \\
\text { slope on crest of first } \\
\text { ridge landward of the } \\
\text { Middle America Trench } \\
4253.8 \mathrm{~m} \\
\text { early mid Quaternary }\end{array}$} & $42-3,9-11$ & 384.1 & $\begin{array}{l}\text { Muddy silt, grayish olive } \\
\text { green with incipient } \\
\text { fissility along same } \\
\text { orientation as bedding, } \\
\text { above and below } 5 \mathrm{~cm} \\
\text { thick graded bed of fine } \\
\text { to very fine sand. Occa- } \\
\text { sional sponge remains. }\end{array}$ \\
\hline & $45-1,103-105$ & 410.5 & $\begin{array}{l}\text { Fine and fine to medium } \\
\text { sand, dark greenish gray } \\
\text { to medium light gray. }\end{array}$ \\
\hline & $46-1,39-41$ & 419.4 & $\begin{array}{l}\text { Muddy silt, very firm } \\
\text { dark greenish gray. Fine } \\
\text { to medium sand, medium } \\
\text { light gray, slightly finer } \\
\text { grained in top } 3 \mathrm{~cm} \text { and } \\
\text { very firm dark greenish } \\
\text { gray muddy silt with } \\
\text { small blebs and discon- } \\
\text { tinuous stringers of fine } \\
\text { to coarse sand. }\end{array}$ \\
\hline $\begin{array}{l}\text { 489A (upper slope, } \\
\text { Middle America Trench } \\
\text { off SW Mexico) } \\
1239.8 \mathrm{~m} \\
\text { early Miocene }\end{array}$ & $\begin{array}{l}30-5,82-85 \\
30-5,100-103 \\
30-5,125-128\end{array}$ & $\begin{array}{l}288.8 \\
289 \\
291\end{array}$ & $\begin{array}{l}\text { Fine to medium-grained } \\
\text { sandstone, olive gray ( } 5 Y \\
3 / 2 \text { ), carbonate-cemented, } \\
\text { with irregular dark, fiber } \\
\text { grained zones. Occasional } \\
\text { shell fragments. Zeolite } \\
\text { filled and unfilled frac- } \\
\text { tures, apparent dips } 40^{\circ}- \\
90^{\circ} \text {. }\end{array}$ \\
\hline $\begin{array}{l}490 \text { (seaward edge, } \\
\text { transition zone between } \\
\text { accretionary zone and } \\
\text { continental crust) } \\
1760.8 \mathrm{~m} \\
\text { Pliocene? }\end{array}$ & $52-1,61-64$ & 465.6 & $\begin{array}{l}\text { Loose fine to medium } \\
\text { sand, olive gray with sub- } \\
\text { angular clasts of biotite, } \\
\text { indurated muddy silt- } \\
\text { stone, olive gray, set in } \\
\text { loose sand. }\end{array}$ \\
\hline $\begin{array}{l}491 \text { (inner slope, } \\
\text { Middle America } \\
\text { Trench, }-2.1 \mathrm{~km} \\
\text { above and }-14.25 \mathrm{~km} \\
\text { NNE of adjacent trench } \\
\text { floor on a steep slope } \\
\text { of }-9^{\circ} \text { ) }\end{array}$ & $21-3,14-18$ & $184.15 \mathrm{~m}$ & $\begin{array}{l}\text { Muddy silt, grayish olive } \\
\text { green, with fine to } \\
\text { medium sand. Sand } \\
\text { occurs as chaotic, } \\
\text { discontinuous beds, and } \\
\text { as burrow fillings. }\end{array}$ \\
\hline \multirow[t]{2}{*}{$\begin{array}{l}2882.8 \mathrm{~m} \\
\text { early Pliocene }\end{array}$} & $43-6,32-33$ & 388.35 & $\begin{array}{l}\text { Muddy siltstone, grayish } \\
\text { olive green (in places soft } \\
\text { to firm silt with fine } \\
\text { sand beds). Interval } \\
\text { sampled lies just beneath } \\
\text { a zone of healed } \\
\text { fractures. }\end{array}$ \\
\hline & $52-1,99-101$ & 467.0 & $\begin{array}{l}\text { Fine to very coarse sand, } \\
\text { unconsolidated, dark } \\
\text { greenish gray with silt, } \\
\text { grayish olive green. Fine } \\
\text { to very coarse sand with } \\
\text { granules and pebbles up } \\
\text { to } 5 \mathrm{~mm} \text {; minor intervals } \\
\text { of silt. }\end{array}$ \\
\hline $\begin{array}{l}492 \mathrm{~A} \\
1934.8 \mathrm{~m} \\
\text { late Pliocene to early } \\
\text { Quaternary }\end{array}$ & $4-1,83-85$ & 14.55 & Glauconitic muddy sand \\
\hline
\end{tabular}

Table 1. (Continued),

\begin{tabular}{|c|c|c|c|}
\hline $\begin{array}{l}\text { Hole, Water Depth, } \\
\text { and Age }\end{array}$ & $\begin{array}{l}\text { Sample } \\
\text { (interval } \\
\text { in } \mathrm{cm} \text { ) }\end{array}$ & $\begin{array}{l}\text { Depth } \\
\text { BSF (m) }\end{array}$ & Core Description \\
\hline \multirow[t]{2}{*}{$\begin{array}{l}492 \mathrm{~B} \\
1942 \mathrm{~m} \\
\text { late Miocene } \\
\text { midslope region }\end{array}$} & $\begin{array}{l}1-2,145-147 \\
1-3,99-101\end{array}$ & $\begin{array}{l}283 \\
284\end{array}$ & $\begin{array}{l}\text { Medium to coarse very } \\
\text { clean sand, medium light } \\
\text { gray, one graded bed } \\
\text { through first } 4 \text { sections, } \\
\text { small clasts (up to } 3 \mathrm{~cm} \text { ) } \\
\text { of fractured shaly } \\
\text { mudstone with shiny } \\
\text { polished fractures. }\end{array}$ \\
\hline & $\begin{array}{l}1-4,147-149 \\
1-5,9-11 \\
1-5,59-61\end{array}$ & $\begin{array}{l}286 \\
286.1 \\
286.6\end{array}$ & $\begin{array}{l}\text { Same as Hole 492B, } \\
\text { except interlayered } \\
\text { medium to coarse sand } \\
\text { and scaly argillite, a well- } \\
\text { lithified mudstone with a } \\
\text { pervasive fabric of } \\
\text { anastomosing polished } \\
\text { and lineated fractures } \\
\text { surfaces. }\end{array}$ \\
\hline \multirow[t]{7}{*}{$\begin{array}{l}493 \text { (upper slope, just } \\
\text { west of a submarine } \\
\text { canyon deeply incised } \\
\text { into the slope) } \\
644.8 \mathrm{~m} \\
\text { early Miocene }\end{array}$} & $37-2,18-23$ & $454.2 \mathrm{~m}$ & $\begin{array}{l}\text { Dark greenish gray } \\
\text { muddy siltstone, bio- } \\
\text { turbated, overprints } \\
\text { primary parallel lamina- } \\
\text { tions; rare inclined, } \\
\text { slickensided fractures } \\
\text { with fine sand beds and } \\
\text { devitrified tuff layers. }\end{array}$ \\
\hline & $49-7,11-13$ & 575.6 & $\begin{array}{l}\text { Irregular pod of coarse } \\
\text { granular-bearing sand } \\
\text { (quartz and metamorphic } \\
\text { clasts) in muddy siltstone. } \\
\text { Bioturbation and slicken- } \\
\text { sides noted in siltstone. }\end{array}$ \\
\hline & $\begin{array}{l}52-1,47-49 \\
52-1,59-61\end{array}$ & $\begin{array}{l}595.5 \\
595.6\end{array}$ & $\begin{array}{l}\text { Complex mixture of } \\
\text { muddy siltstone and sand- } \\
\text { stone, olive gray, rich in } \\
\text { quartzose granules and } \\
\text { shell fragments. Granules } \\
\text { angular to moderately } \\
\text { well rounded. Mixture } \\
\text { due to loading and/or } \\
\text { slumping. Sandstone } \\
\text { cemented by calcite. } \\
\text { Common straight frac- } \\
\text { tures, } 0^{\circ}-90^{\circ} \text {, slicken- } \\
\text { sided, various orienta- } \\
\text { tions. }\end{array}$ \\
\hline & $53-1,8-9$ & 604.6 & $\begin{array}{l}\text { Calcareous coarse to very } \\
\text { coarse sandstone with } \\
\text { shell fragments. }\end{array}$ \\
\hline & $53-1,63-65$ & 605.15 & Muddy sandstone \\
\hline & $\begin{array}{l}54-2,98-100 \\
54-2,114-116\end{array}$ & $\begin{array}{l}616.5 \\
616.7\end{array}$ & $\begin{array}{l}\text { Olive gray muddy } \\
\text { siltstone, fissile sub- } \\
\text { parallel to bedding, bed- } \\
\text { ding faint, faint bioturba- } \\
\text { tion with fine sand layers. } \\
\text { Bedding up to } 22^{\circ} \text { true, } \\
\text { fractures dip } 57^{\circ}-85^{\circ} \text {. }\end{array}$ \\
\hline & $54-5,127-129$ & 621.3 & $\begin{array}{l}\text { Muddy siltstone, olive } \\
\text { gray, fissile subparallel to } \\
\text { bedding, bedding faint } \\
\text { bioturbation faint, with } \\
\text { fine sand layers. } 12^{\circ} \text { true } \\
\text { dip, } 19^{\circ} \text { apparent dip. }\end{array}$ \\
\hline
\end{tabular}

minifers (Fig. 5). Pyrite is found with either type of calcite.

\section{Other Diagenetic Features}

Authigenic pyrite also occurs as aggregates along basal cleavage planes in biotite. The paucity of biotite in Site 489 sandstones may be due to its replacement by pyrite. Thin sections of recent sediments from the upper slope of the Middle America Trench show a similar relationship between pyrite and biotite (Fig. 6), indicating that the replacement process begins very early in the diagenetic sequence. 


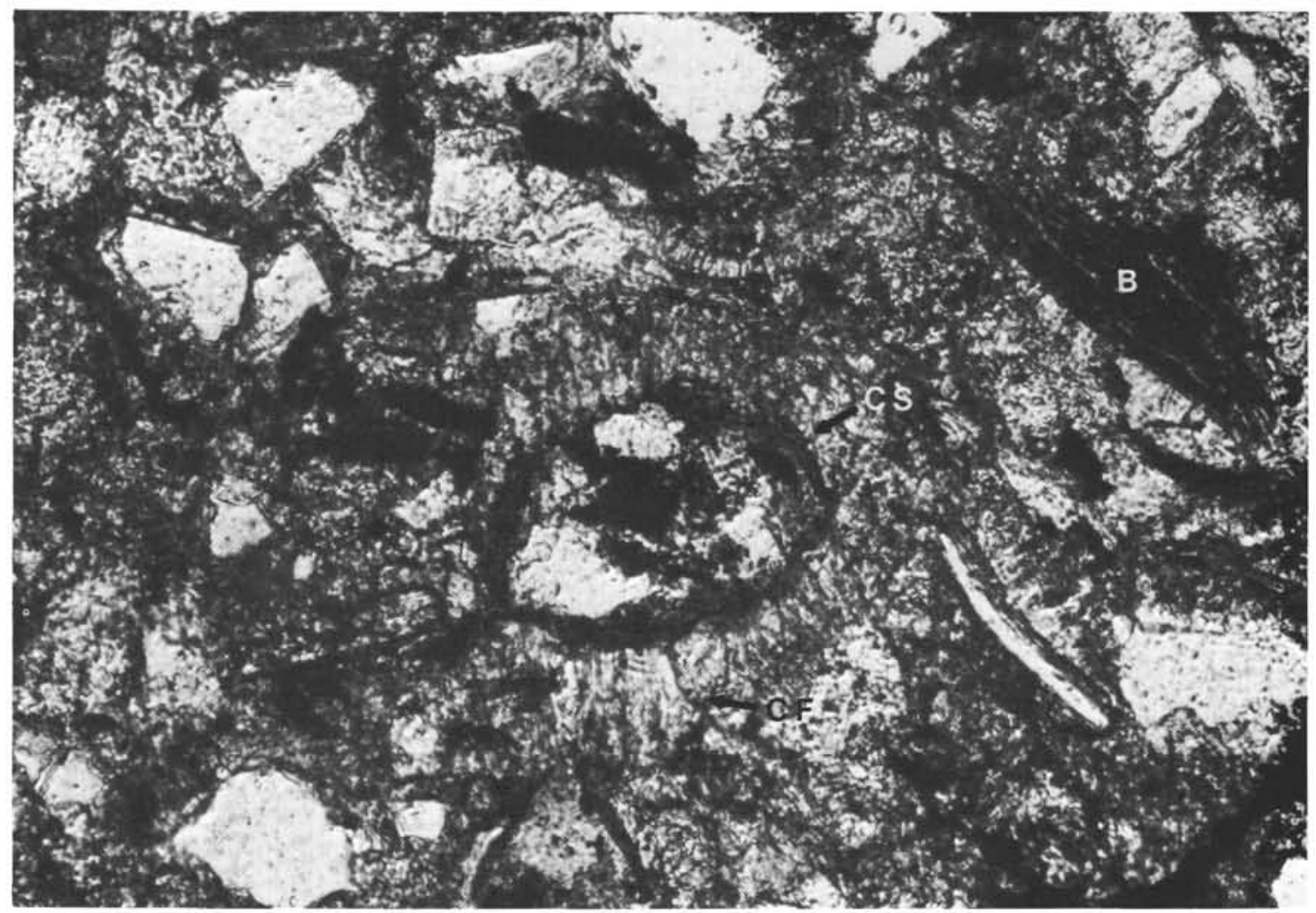

Figure 3. Framework grain (center) with a clay skin (CS), surrounded by later iron-free fibrous calcite cement (CF). Note bloated biotite (B) in the upper right-hand corner. (Hole 489A, $291 \mathrm{~m} \mathrm{BSF}$, early Miocene; field of view is $0.55 \times 0.85 \mathrm{~mm}$.)

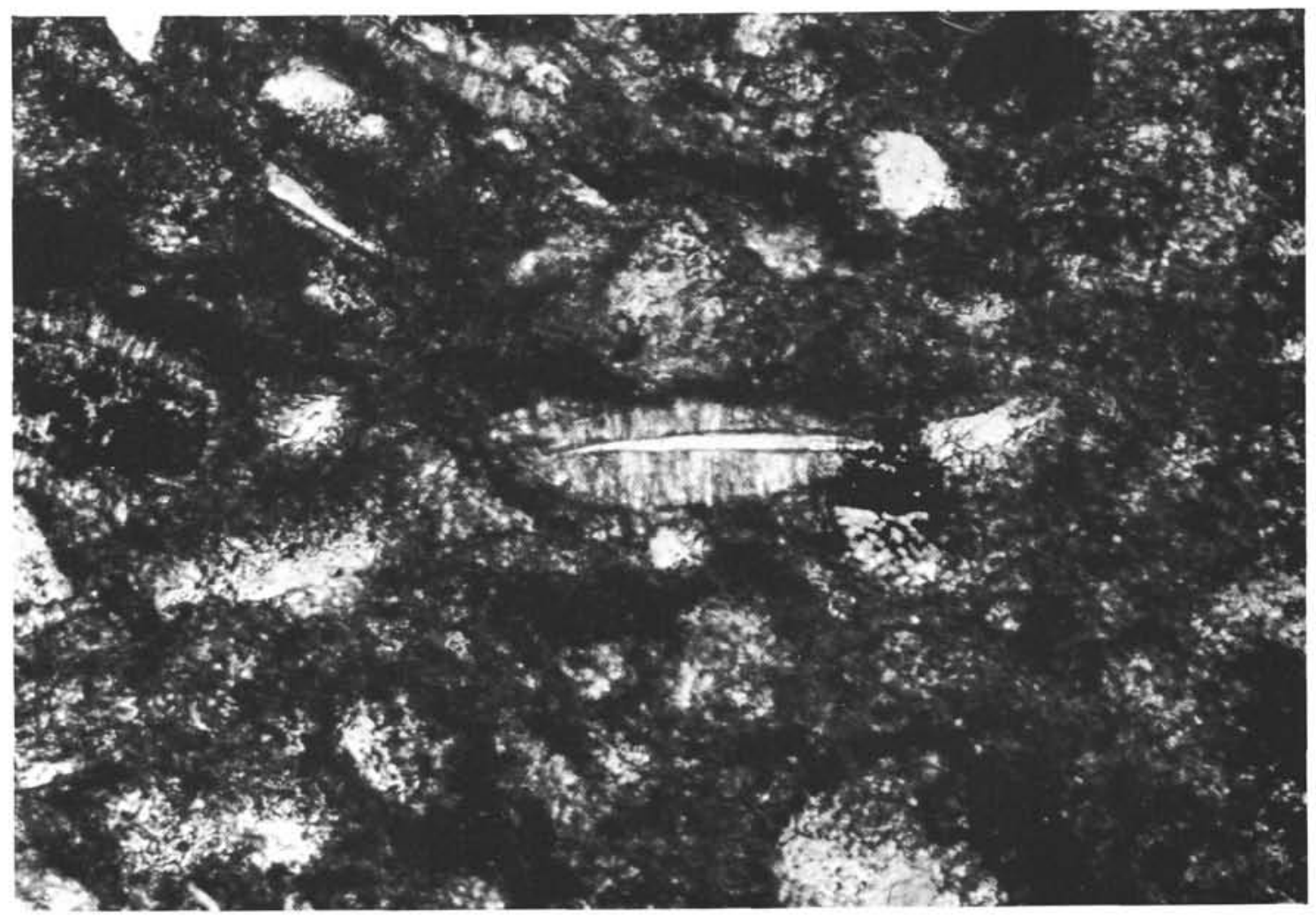

Figure 4. Fibrous iron-free calcite cement on detrital muscovite (center) surrounded by later iron-free micritic calcite. (Hole $489 \mathrm{~A}, 288.8 \mathrm{~m}$ BSF, early Miocene; field of view is $0.55 \times 0.85 \mathrm{~mm}$.) 


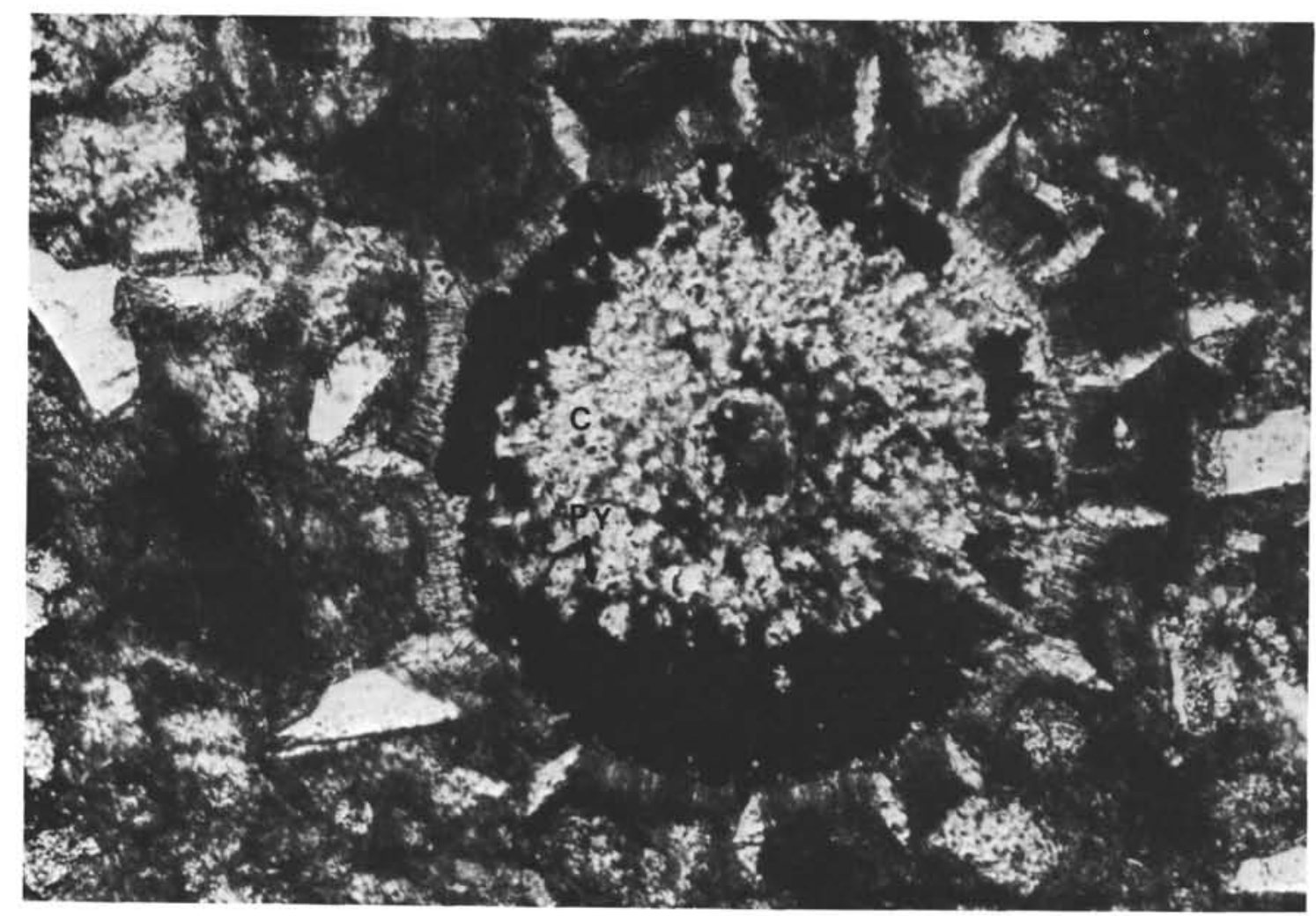

Figure 5. Sequence of chamber-filling authigenic minerals: geopetal framboidal pyrite (PY) and later sparry calcite (C). (Hole 489A, $291 \mathrm{~m} \mathrm{BSF}$, early Miocene; field of view is $0.55 \times 0.85 \mathrm{~mm}$.)

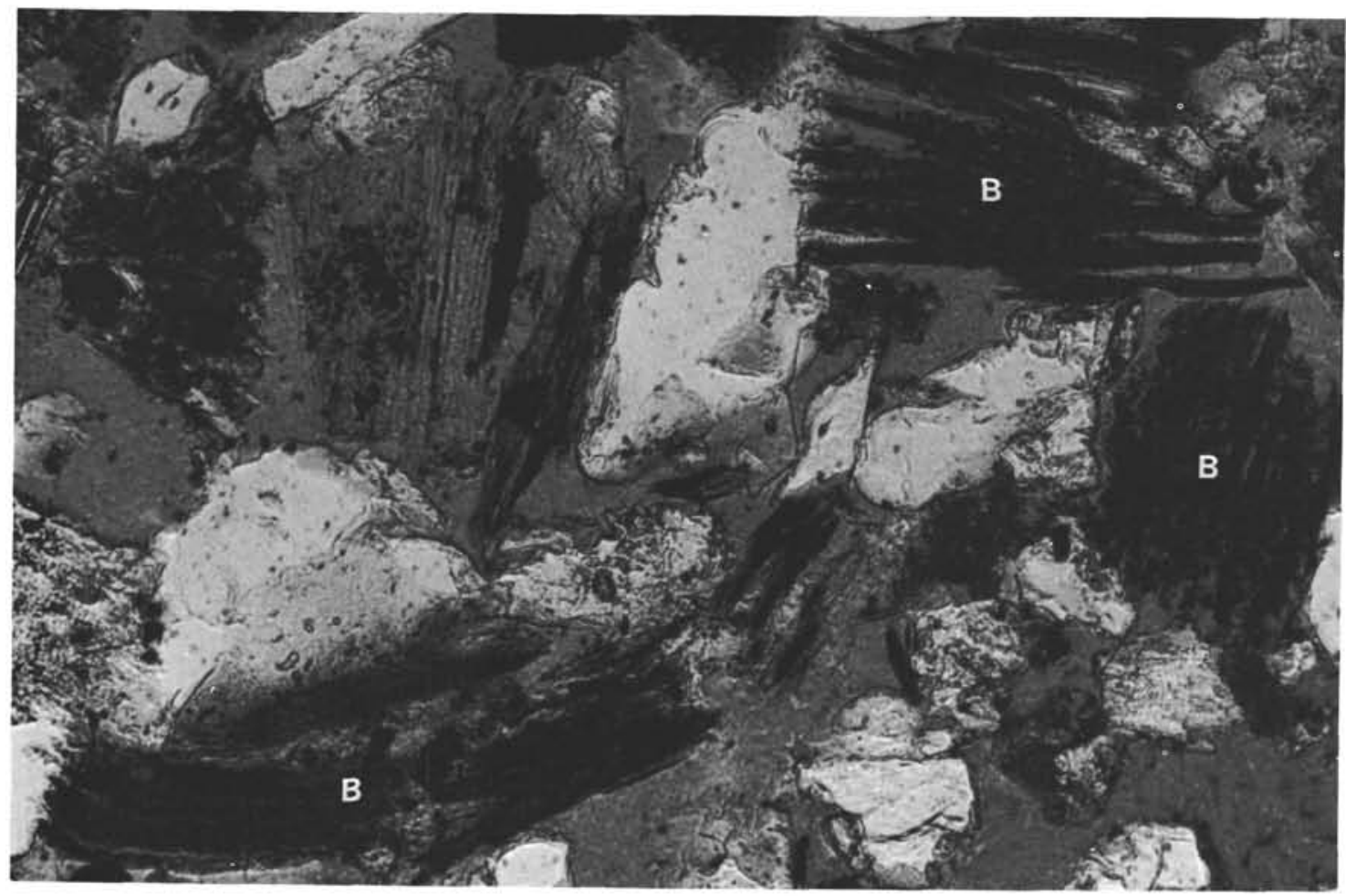

Figure 6. "Bloated" biotite (B) grains in a recent sediment from the upper slope region, of fshore Oaxaca, Mexico. (Field of view is $0.55 \times 0.85 \mathrm{~mm}$.) 


\section{Site 493}

Site 493, the continental reference hole, is situated approximately $16 \mathrm{~km}$ landward of Site 489 (Fig. 1). Four lithologic units comprise 393 meters of section that were recovered from the three holes drilled at this site (Fig. 2). Unit 1 is composed of Quaternary muddy silt, and Unit 2 consists of late Miocene and Pliocene muddy silt(stone) and mud(stone). Unit 3 is an early Miocene fining-upward sequence of muddy siltstone to sandstone, in turn underlain by a basal unit of diorite.

Nine representative samples from Unit 3 were selected for this study and include both thin sands interbedded with mudstones and sandstones from the 30 meter interval overlying the basement. The finer-grained sandstones are plagioclase-dominant arkoses, whereas the coarser-grained sandstones are perthite-dominant arkoses (McBride, 1963). Accessory biotite, muscovite, chlorite, glauconite, epidote, hornblende, zircon, and microfossils are present. Unlike the sandstones from Site 489 , the sands and sandstone from Site 493 vary considerably in texture. Upper slope processes such as bioturbation, slumping, and loading have produced complex mixtures of mud and sand. The abundance of mud in slumped and bioturbated sediments ranges from $3 \%$ to $60 \%$ and averages $36 \%$.

\section{Cementation History}

Calcite, gypsum, and pyrite are the major cementing minerals in sandstones from Site 493. Calcite and gypsum are mutually exclusive, but pyrite is commonly associated with both cements. The calcite-cemented sandstones display a paragenetic sequence similar to that of sandstones from Site 489: an initial stage of clay skin development followed by the precipitation of isopachous calcite cement and a final stage of micritic to sparry calcite and granular pyrite cementation. The clay skins and isopachous cement are best developed in the very fine-grained sandstones at depth. The fibrous calcite cement most commonly rims biotite and muscovite. Stage 3 sparry calcite also occurs along fractures in framework grains, including quartz, feldspar, and calcareous microfossils (Fig. 7).

Siderite concretions are present locally in the very fine-grained sandstones. Early growth of the concretions is indicated by closer packing of the framework grains immediately adjacent to them. Although this relationship suggests that the siderite was precipitated prior to Stage 3 calcite, there is no evidence to indicate the timing relative to Stages 1 and 2 .

In addition to the cements described previously, there is a complex sequence of chamber-filling cements in the calcareous sandstones; it begins with geopetal pyrite framboids, followed by cristobalite, and finally by ironfree sparry calcite. There is no ferroan calcite in sandstones from Site 493.

The four gypsiferous sandstones from Site 493 are very muddy $(40 \%-60 \%$ mud). The abundance of clayrich matrix has directly influenced diagenetic reactions in these rocks. The deepest and most coarse-grained sandstone is cemented by clay skins and fibrous, voidfilling gypsum. The relative timing of these two cements could not be ascertained in thin section.

There are several fracture-filling cements in these sandstones. Examination of spatial relationships of authigenic minerals in foraminifer chambers and fractures revealed the following order of precipitation: (1) pyrite and phillipsite, (2) gypsum, and (3) cristobalite (Fig. 8). The absence of calcite as a cementing agent in the gypsiferous sandstones cannot be explained by a lack of sufficient allochems to act as nucleation sites for calcite because allochems are equally abundant in calcite- and gypsum-cemented sandstones. A comparison of grain-to-matrix ratios in calcite- vs. gypsum-cemented sandstones shows that those sandstones with a grain-tomatrix ratio less than 2:1 are gypsiferous, whereas those with a grain-to-matrix ratio greater than $2: 1$ are calcareous; this relationship suggests that permeability determined whether calcite-precipitating fluids were able to migrate through the sands. An alternative explanation is that carbonate and sulphate ions in solution completed for the uptake of dissolved calcium and that local geochemical factors determined whether calcite or gypsum precipitated (Galloway, personal communication).

\section{Chemical Alteration of Framework Grains}

The interaction of framework grains with pore fluids has caused chemical changes in some of the less stable components. Diagenetic features observed in detrital grains of Site 493 sandstones include (1) the vacuolization of plagioclase; (2) the alteration of potassium feldspar; (3) the alteration of biotite to chlorite and pyrite; (4) the partial dissolution of hornblende; (5) the micritization of calcareous microfossils; and (6) the inversion of aragonitic fossils to calcite.

\section{Sources of Calcite Cement}

The abundance of biogenic debris in calcite-cemented sandstones from the upper slope sequence implies that the source of the cement is allochthonous. Biostratigraphic data indicate that late Miocene through Quaternary sediments were deposited in low-oxygen conditions; this information, together with the release of moderate amounts of methane gas from core liners, led to the inference that the calcite cement was methanederived. However, subsequent carbon isotope analyses of sandstones from Sites 489 and 493 reveal $\delta^{13} C_{\text {PDB }}$ values ranging from $-12.2 \%$ to $+12.1 \%$; data on carbon isotope values for methane (cf. Hudson, 1977) show $\delta^{13} \mathrm{C}_{\mathrm{PDB}}=-30 \%$ and lighter. Clearly, the calcite cement is not methane-derived. Furthermore, the $\delta^{13} \mathrm{C}$ value of the carbonate cements are obscured by $\delta^{13} \mathrm{C}$ values derived from biogenic components. Two samples with less than $2 \%$ of biogenic debris have $\delta^{13} \mathrm{C}$ values of $+12.1 \%$ and $+9.6 \%$, indicating that the true $\delta^{13} \mathrm{C}$ value of the cement is somewhere in this range. Perhaps the carbon for these cements has been derived from residual organic matter following methane production and migration from the system (cf. Hudson, 1977). 


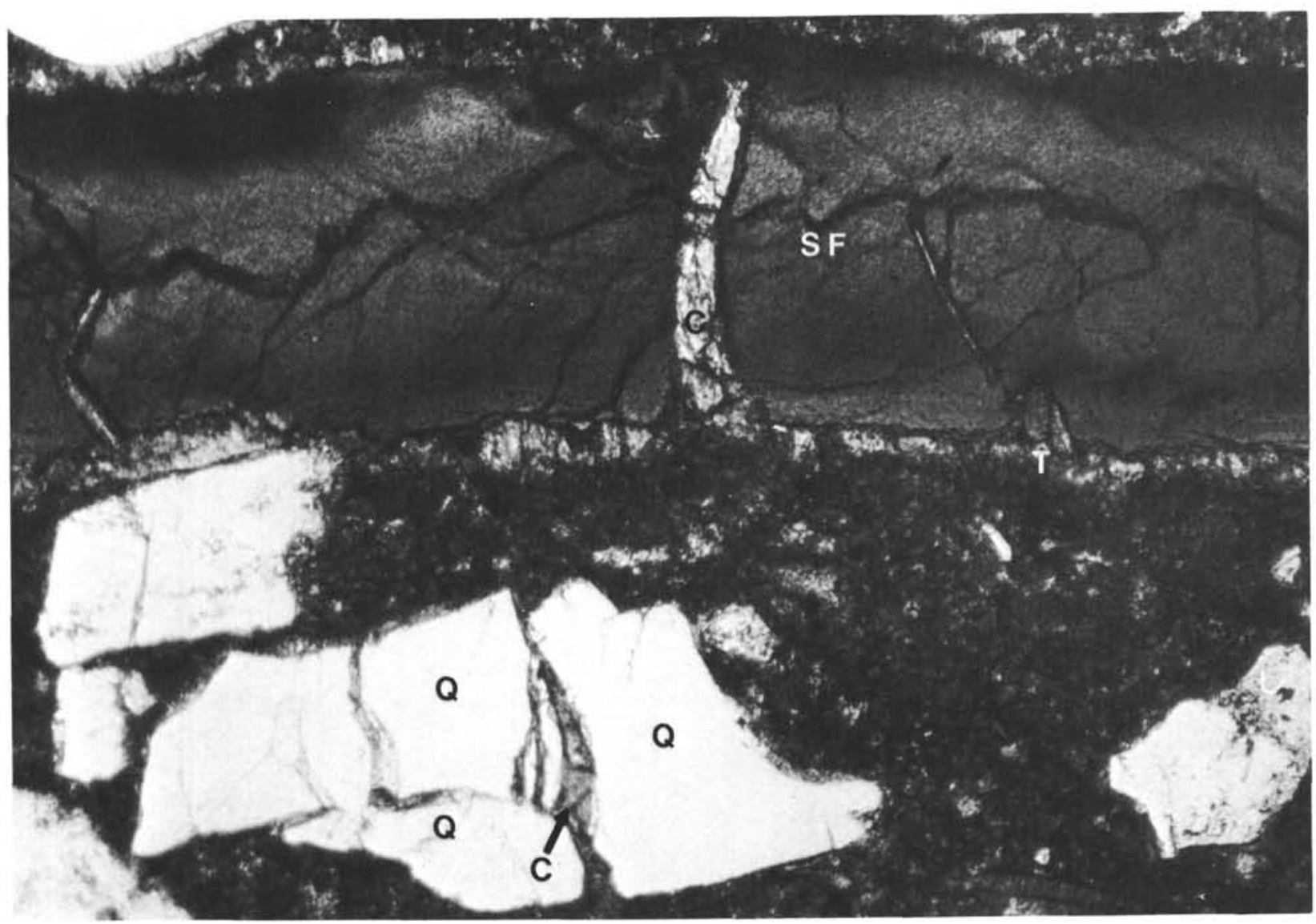

Figure 7. Sparry calcite (C) filling fractures in a shell fragment (SF) and in a detrital quartz grain (Q); incongruent spacing between framework grains indicates that some grains have been replaced by micritic calcite cement (grainy dark areas). (Hole 493, $616.5 \mathrm{~m} \mathrm{BSF}$, early Miocene; field of view is $1.4 \times 2.2 \mathrm{~mm}$.)

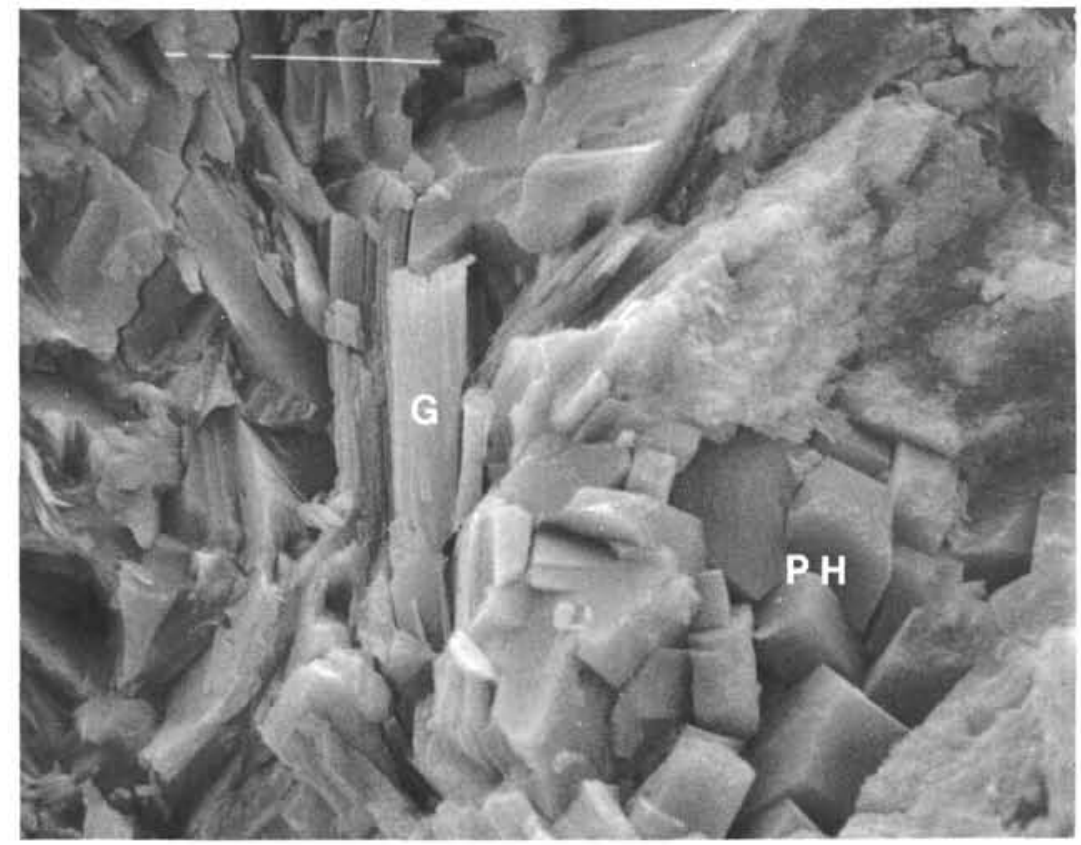

Figure 8. Sequence of fracture-filling authigenic minerals: phillipsite $(\mathrm{PH})$ followed by fibrous gypsum (G). (Hole 493, 595.6 m BSF, early Miocene; scale bar is $10 \mu \mathrm{m}$.) 


\section{MID- TO LOWER SLOPE SANDS}

\section{Site 491}

Site 491 is located on the inner slope of the Middle America Trench, about $2.1 \mathrm{~km}$ above and $14.25 \mathrm{~km}$ north-northeast of the adjacent trench floor on a steep slope of $9^{\circ}$ and at a water depth of 2883 meters (Fig. 1). Three lithologic units occur in the nearly 388 meters of section recovered: (1) late Pliocene to late Quaternary mud, (2) early to late Pliocene muddy silt with minor fine sand layers, and (3) late Pliocene muddy silt to muddy siltstone interbedded with fine to coarse-pebbly sand (Fig. 2). Two samples from Unit 2 (184 $\mathrm{m}$ and 388 $\mathrm{m} \mathrm{BSF}$ ) and one sample from Unit 3 (467 m BSF) were selected for petrographic analysis. All samples are early Pliocene plagioclase-dominant subarkoses (McBride, 1963 ) and contain about $25 \%$ pseudomatrix (Dickinson, 1970). Texturally, the sediments consist of very poorly sorted, very fine- to medium-grained muddy sand lenses in very fine sandy mud.

\section{Diagenetic Features}

The diagenetic alteration of chemically and mechanically unstable components in sediments from Site 491 bas produced the following features:

1) The partial dissolution and vacuolization of feldspars, primarily plagioclase;

2) the "bloating" of detrital muscovite and biotite;

3 ) the formation of hematite coats around framework grains;

4) the deformation of ductile components-mud clasts, volcanic rock fragments, and phyllosilicates;

5 ) the growth of muscovite and chlorite on extremely vacuolized feldspars in the matrix; and

6) the development of tectonic fractures that transect grain boundaries.

Features 1,2, and 3 are common in all samples, whereas features 4,5 , and 6 are characteristic of the deepest sample only. These trends may reflect the influence of grain size as well as depth upon diagenetic reactions in marine sediments. More detailed sampling of sediments at this site is needed to substantiate the diagenetic sequence.

\section{Site 492}

Site 492 , located on the midslope of the Middle America Trench region, was drilled in 2000 meters of water (Fig. 1). Two lithologic units were recovered in the 279 meters of sediment penetrated (Fig. 2); these include an upper unit of Quaternary to late Miocene mud and mudstone $(0-247 \mathrm{~m})$ and a lower unit of late Miocene mudstone interbedded with sand and granular gravel (247-290 m). One sample of a glauconitic sand from Unit 1 (14 m BSF) and six samples of unconsolidated sands from Unit 2 (281-287 m BSF) were selected for this study. The glauconitic sand from Unit 1 is late Pliocene to early Quaternary in age, and the Unit 2 sands are believed to be middle to late Miocene.

The major framework component of the shallowest sand is glauconite, which comprises $86 \%$ of the grain population and about $53 \%$ of the whole sample (Fig. 9A). Detrital quartz and plagioclase occur in subequal amounts, with minor calcareous fossils, primarily foraminifers. Approximately $34 \%$ of the sediment is pseudomatrix, which consists of compactionally deformed mud clasts that are often associated with coccoliths and foraminifer tests (Fig. 9B). Authigenic minerals include patchy occurrences of fibrous gypsum cement (Fig. 9A), ubiquitous oxidized pyrite, and local zeolite.

The unconsolidated medium- to coarse-grained sands of Unit 2 are plagioclase- and plutonic rock fragmentdominant lithic arkoses (McBride, 1963). The sands can be divided into two subunits on the basis of grain size and diagenetic features. The most conspicuous feature of the shallower sands (281-284 m) is the network of pervasive fractures in detrital grains (Fig. 10, 11, and 12). The apparent lack of grain rotation in these sands suggests that the fracturing occurred either postcompaction, in conjunction with the uplift of the midslope region, or as a result of compaction following decementation. There are no indications that these sands were previously cemented, except for the system of "canals" in some framework grains that resemble those produced by calcite wedging in sandstones from Site 493 . In this case, decementation would have occurred before significant replacement of framework grains by calcite. Although no "remnant" calcite was found while traversing the thin sections, the possibility of a former cementation event should not be ruled out.

Intergranular illite and chlorite are common in the deeper sands (Figs. 13 and 14). The chlorite probably formed as an alteration product of detrital biotite, as indicated by (1) the presence of chloritized biotite in shallower samples and (2) the slight degree of compaction of the deeper samples, which makes chlorite development by recrystallization unlikely.

Detrital grains in sands from Site 492 show both chemical and mechanical alteration. Plagioclase and potash feldspars are dissolved along cleavage and twin planes, and some grains are sericitized and vacuolized. Embayed edges on hornblende grains suggest that these were also corroded. Detrital biotite is usually bloated; fresh biotite grains are typically kinked. Dissolution features are also common in calcareous fossil fragments.

\section{Site $\mathbf{4 8 8}$}

Site 488 is located on the crest of the first ridge landward of the Middle America Trench (Fig. 1); seismic data from the area have been interpreted by Shipley and others (1980), who suggest that the ridge represents the toe of an accretionary zone. Two lithologic units were recovered from the $\mathbf{4 2 8}$ meters of section penetrated (Fig. 2). The upper unit, 313 meters thick, is composed of lower middle to upper Quaternary muddy silt(stone) and mud(stone) with local thin silt and muddy sand beds near the base. The lower unit consists of lower middle Quaternary mud(stone), sand, and pebbly sand. The section is interpreted as a slope sequence mantling coarser-grained, uplifted trench deposits. Three samples were selected from Unit 2 at depths of 384,410 , and 419 meters BSF. The samples are plagioclase- and plutonic rock fragment-dominant arkose to lithic arkose (McBride, 1963). 

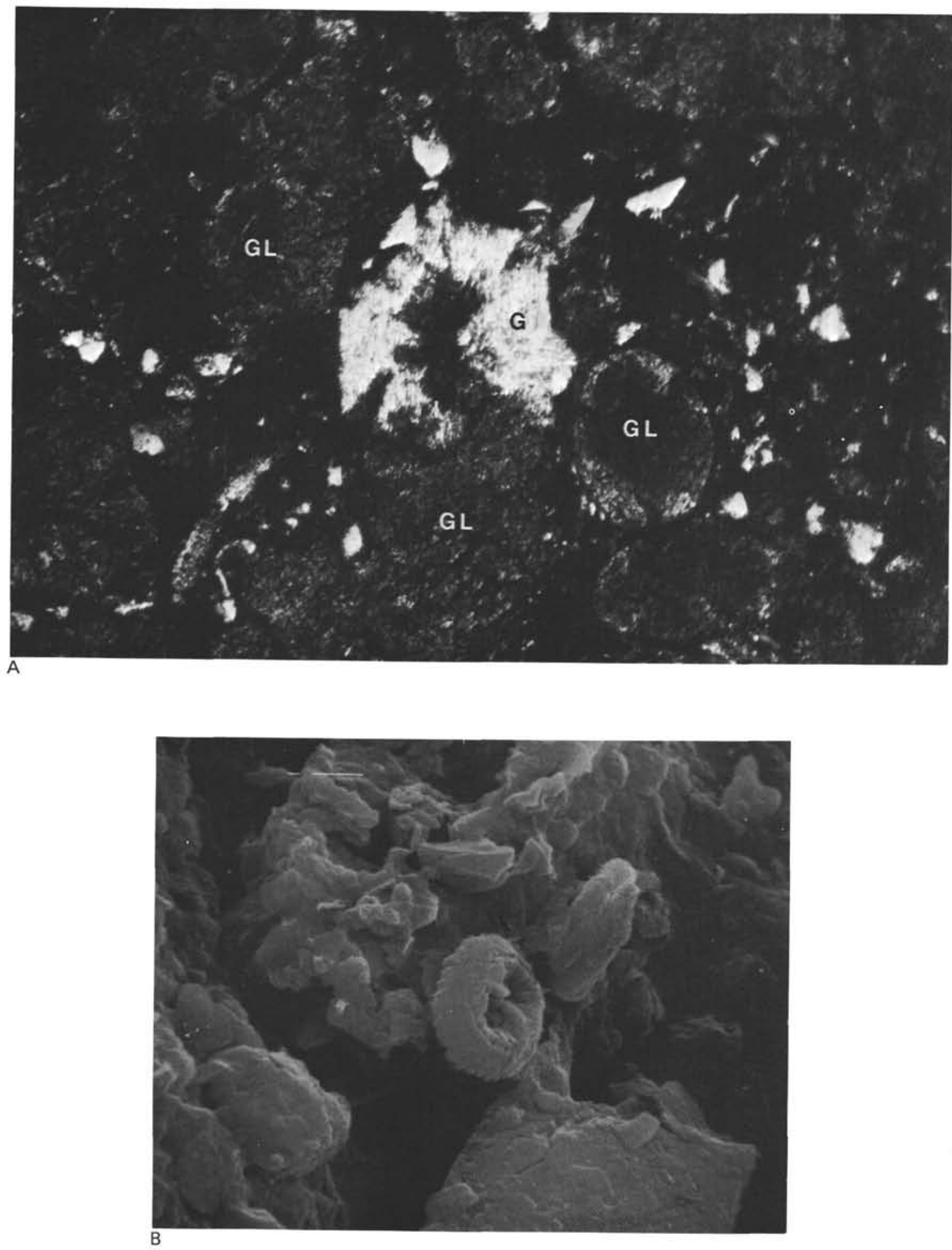

Figure 9. A. Fibrous, pore-filling authigenic gypsum (G) in glauconitic (GL) sandstone. (Hole 492A, $14.5 \mathrm{~m}$ BSF, late Pliocene to early Quaternary; field of view is $1.4 \times 2.2 \mathrm{~mm}$.) B. Matrix in glauconitic sand includes coccoliths and deformed mud clasts. (Hole 492A, $14.5 \mathrm{~m}$ BSF, late Pliocene to early Quaternary; scale bar is $1 \mu \mathrm{m}$.)

Site 488 sands have a more abundant and diverse accessory mineral assemblage than any of the sites discussed previously. Biotite, hornblende, pyroxene, sphene, chlorite, garnet, and opaque minerals are concentrated along subparallel surfaces and define the bedding described from the core. The "incipient fissility" also noted in the cores has resulted from the planar arrangement of mud clasts and their subsequent deformation during compaction. The degree of compaction increases with increasing depth in the core, which may be a function either of increased depth of burial or of an increase in the percentage of ductile components with 


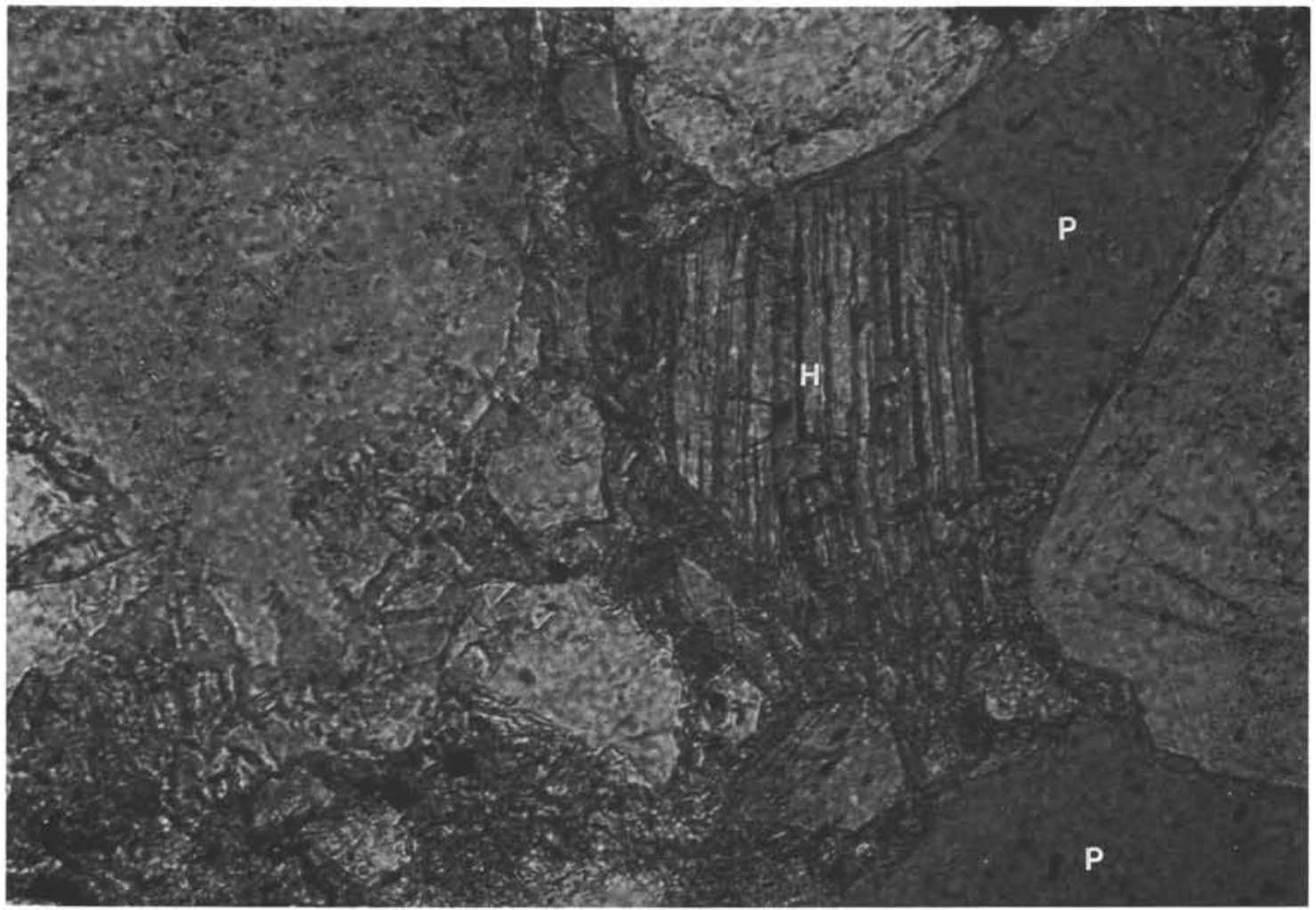

Figure 10. Fractured detrital hornblende $(\mathrm{H})$ between less brittle framework grains; $\mathrm{P}=$ pore space. (Hole $492 \mathrm{~B}, 284 \mathrm{~m}$ BSF, middle to late Miocene; field of view is $0.55 \times 0.85 \mathrm{~mm}$.)

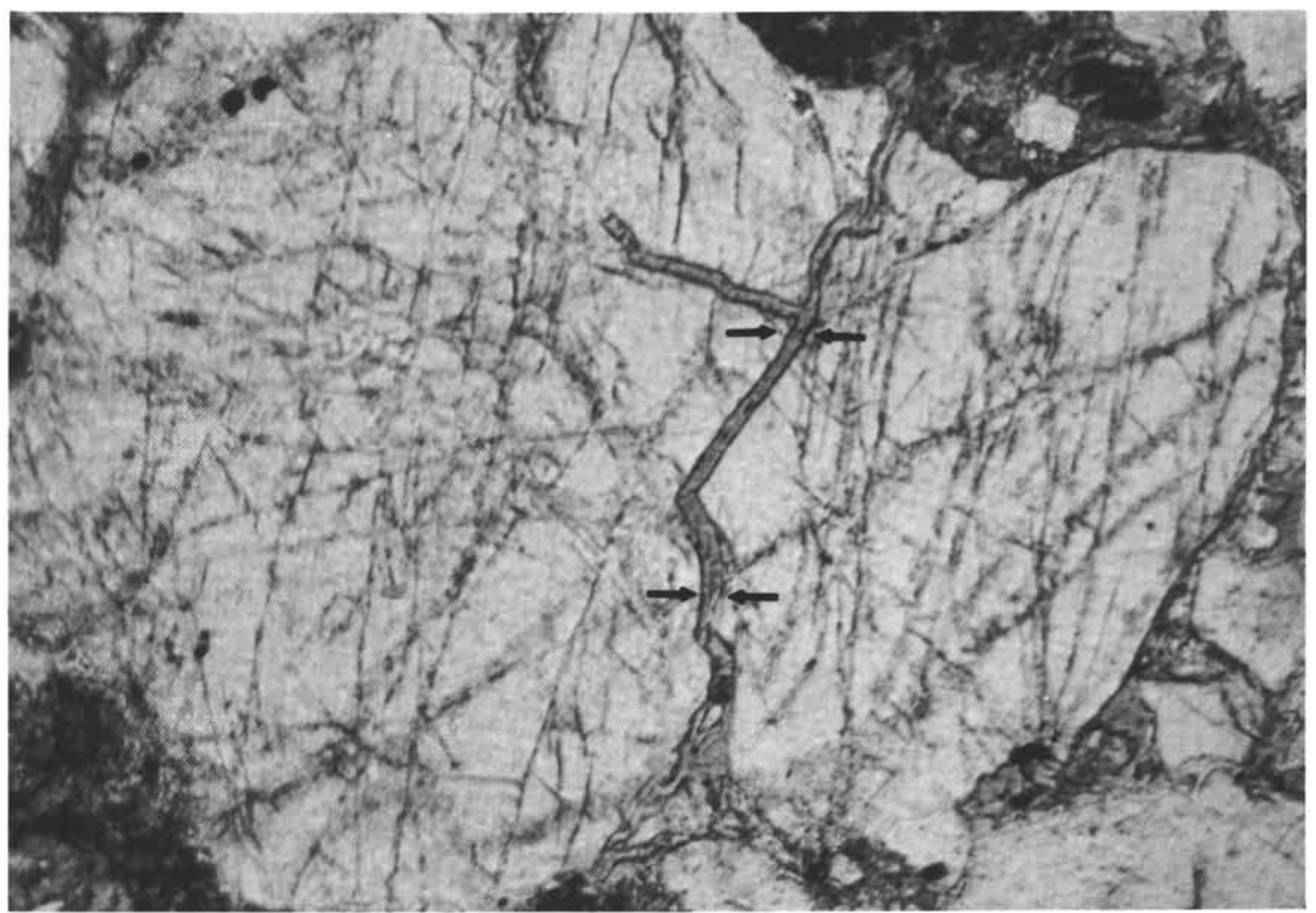

Figure 11. "Canal" system (arrows) in detrital polycrystalline quartz. Note the uniform width of the canals, indicating a lack of compaction and grain rotation following the development of fractures. (Hole 492B, $284 \mathrm{~m}$ BSF, middle to late Miocene; field of view is $1.4 \times 2.2 \mathrm{~mm}$.) 


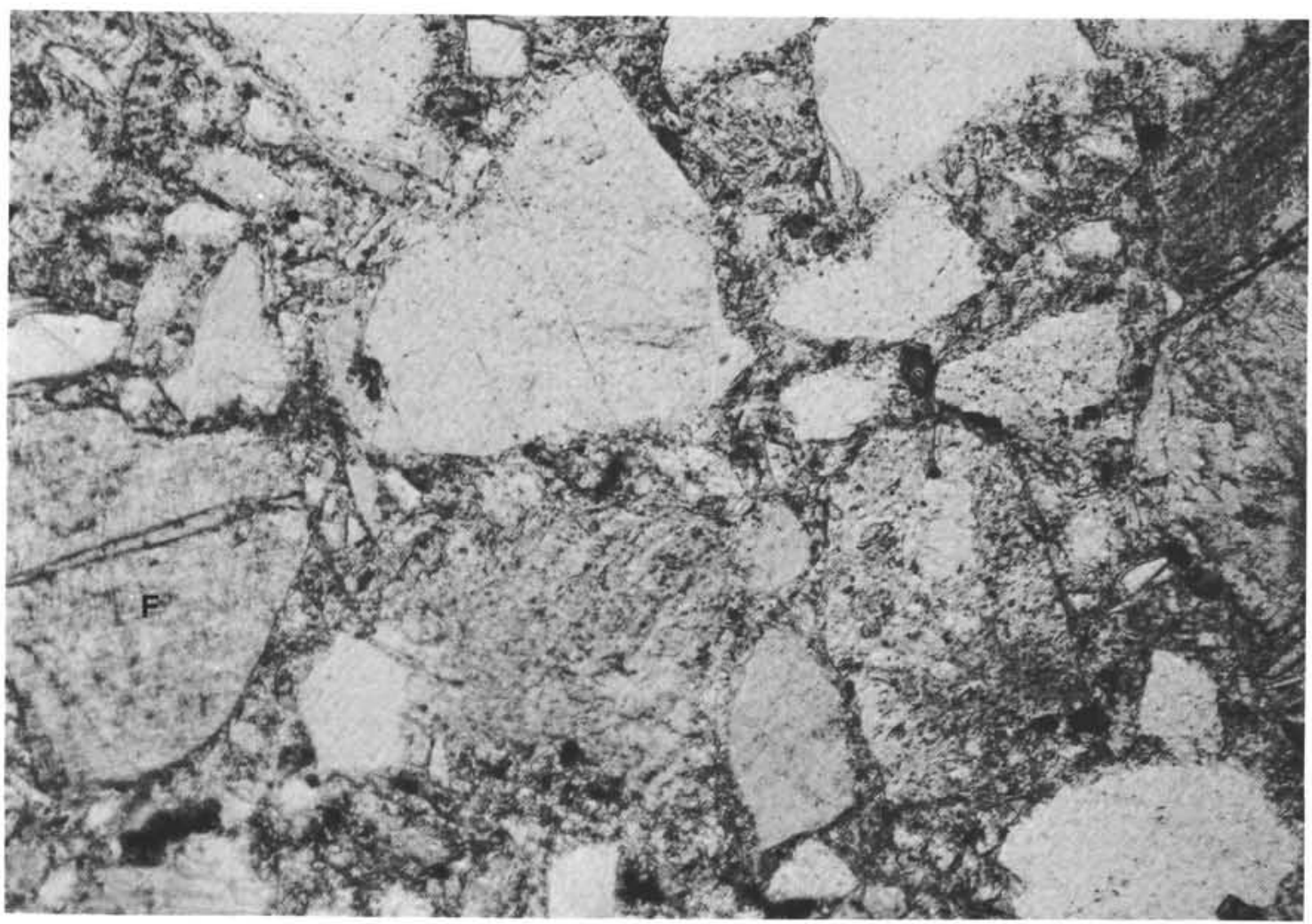

Figure 12. Representative sand from Site 492 , showing a very poorly sorted texture with a silty matrix. Clay is much less abundant in this sample than in the sample from Figure 13, a finer-grained sand from the same hole. Note wedge in feldspar grain (F). (Hole 492B, $281 \mathrm{~m} \mathrm{BSF}$, middle to late Miocene; field of view is $1.4 \times 2.2 \mathrm{~mm}$.)

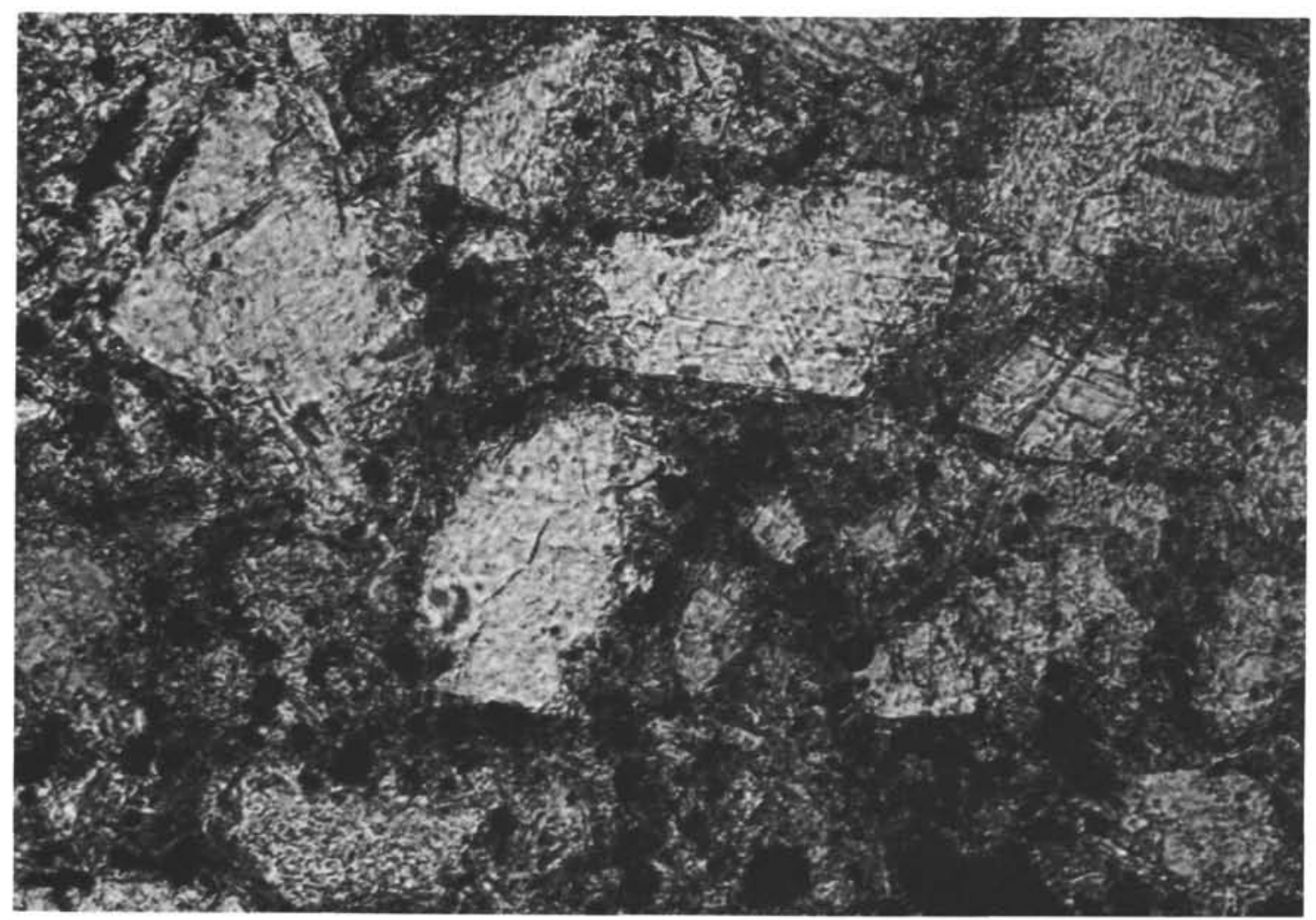

Figure 13. Abundant intergranular illite and chlorite in fine-grained sands. (Hole 492B, $286 \mathrm{~m}$ BSF, middle to late Miocene; field of view is $0.55 \times 0.85 \mathrm{~mm}$.) 


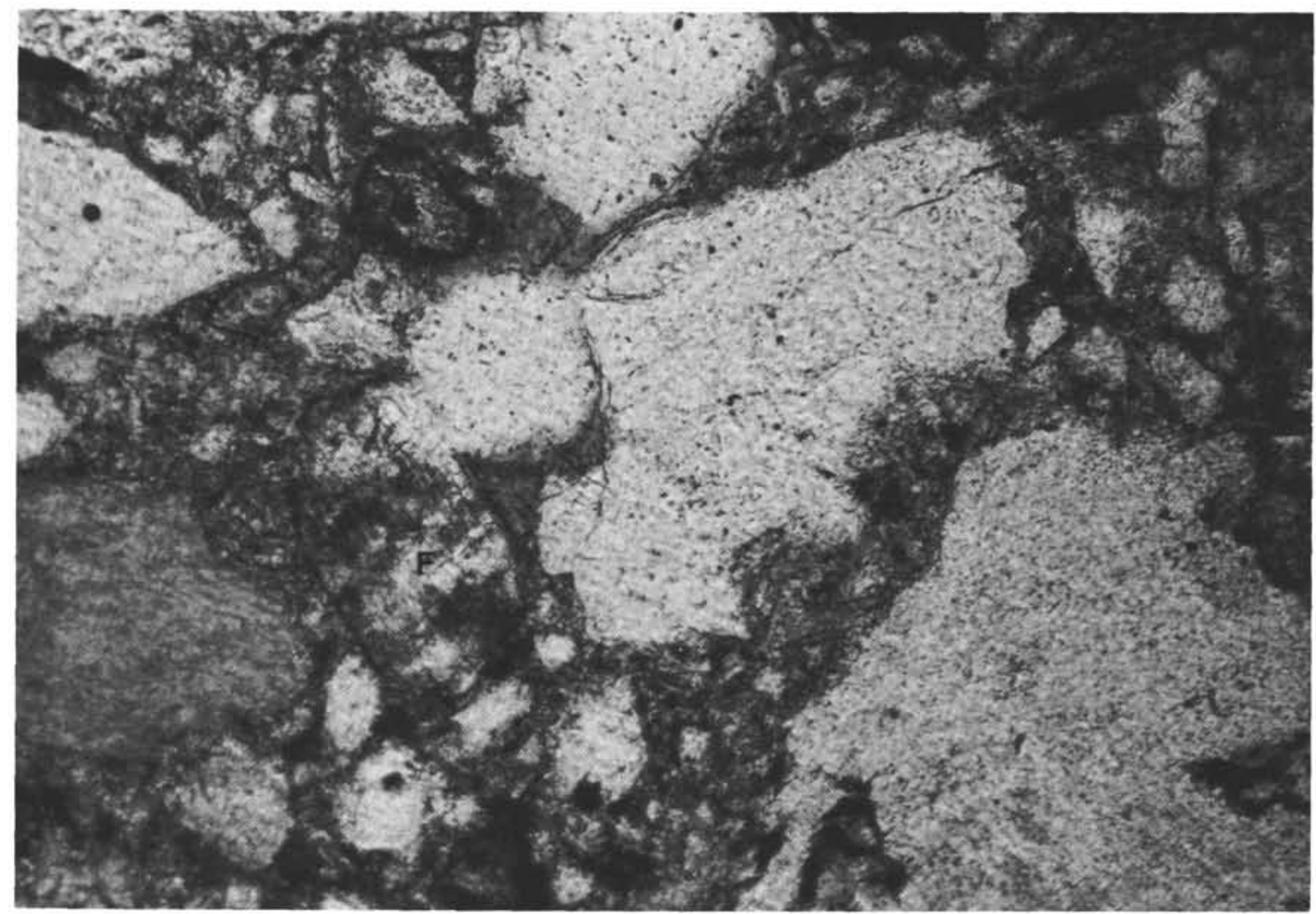

Figure 14. Abundant intergranular matrix in coarse-grained deeper sands; clay has partially replaced a detrital feldspar (F). (Hole 492B, $286.1 \mathrm{~m}$ BSF, middle to late Miocene; field of view is $1.4 \times 2.2 \mathrm{~mm}$.)

depth. These observations are consistent with the increase in bulk density and corresponding decrease in porosity and water content that have been measured in the core.

Two major diagenetic reactions are evident in sands from Site 488: (1) the dissolution of chemically unstable framework grains, such as hornblende, pyroxene, potash and plagioclase feldspars, and calcareous microfossils; and (2) the production of pseudomatrix by the compaction of mud clasts and volcanic rock fragments and the kinking and chloritization of biotite. Both reactions are accelerated with increasing depth in the core. The total percentage of matrix in the upper two samples is less than $5 \%$, primarily because these sands are fine to medium grained and contain fewer rock fragments. In these samples, clay matrix is usually produced by the deformation of biotite and its chemical alteration to chlorite. The resultant texture is similar to that observed in the lower sequence of Site 492 sands.

\section{TRENCH SANDS}

\section{Site $\mathbf{4 8 6}$}

Two holes, 486 and $486 \mathrm{~A}$, were drilled at Site 486 , located in the Middle America Trench $120 \mathrm{~km}$ southeast of Acapulco, Mexico (Fig. 1). Thirty-eight meters of predominantly fine to medium clayey sand were recovered from Hole 486, and 22 meters of fine to medium clayey sand and very coarse sand were recovered from Hole 486A (Fig. 2). The entire section consists of unconsolidated Quaternary sand and muddy sand that contain shelf-derived faunal elements. A shipboard seismic reflection profile along the axis of the trench indicates that the turbidite fill in the trench is discontinuous; Site 486 is located in one of the sediment ponds.

Thirteen representative samples $(9.5-31.4 \mathrm{~m})$ of unconsolidated sands from Site 486 were selected for this study. The coarse to very coarse sands are plagioclasedominant lithic arkoses (McBride, 1963); plutonic rock fragments are the most abundant lithic type near the top of the sequence, and carbonate rock fragments are the dominant lithic type near the base. The fine- to mediumgrained sands are plutonic rock fragment-dominant lithic arkoses to lithic subarkoses (McBride, 1963) that contain subequal amounts of potassium and plagioclase feldspars.

Based upon the depth-related diagenetic trends observed in sands from the lower slope (Sites 491, 492, and 488 ), one would predict a progressive increase in the occurrence of dissolution features and production of matrix with increasing depth in the trench sands. Although these trends apply in a general sense, there are distinct differences between diagenetic features in the coarser-grained sands and those observed in the finergrained sands. The coarser-grained sands are richer in chlorite and illite, which have probably been redistributed by circulating pore waters to form thin films around framework grains (Figs. 15 and 16). This type of mechanically dispersed "matrix" usually comprises about $6 \%$ of the sediment. 


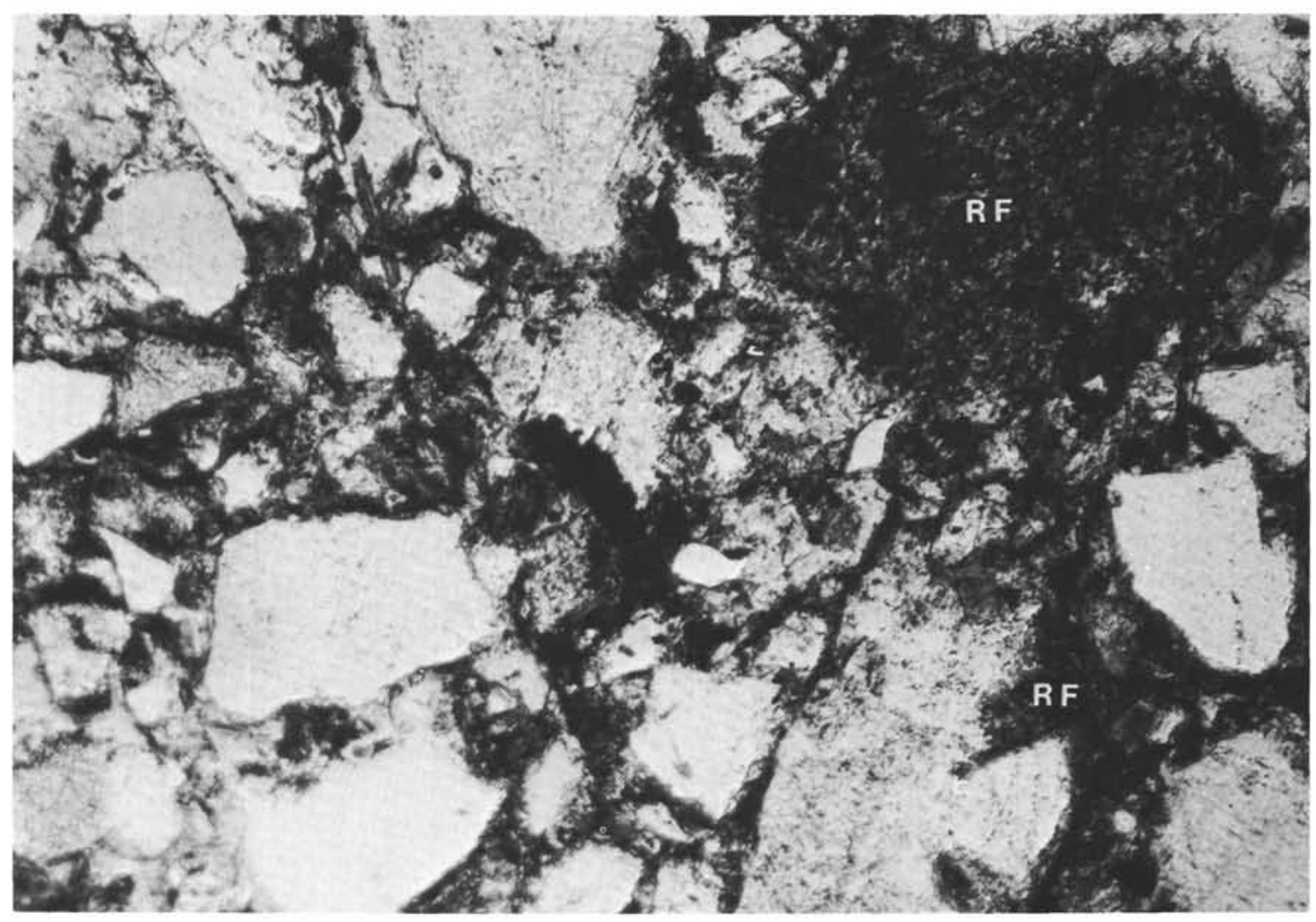

Figure 15. Representative poorly sorted, coarse-grained trench sand with common intergranular chlorite and illite (dark areas between detrital grains). Argillaceous rock fragments (RF) compacted in some areas. (Hole 486, $9.5 \mathrm{~m} \mathrm{BSF}$, Quaternary; field of view is $1.4 \times 2.2 \mathrm{~mm}$.)

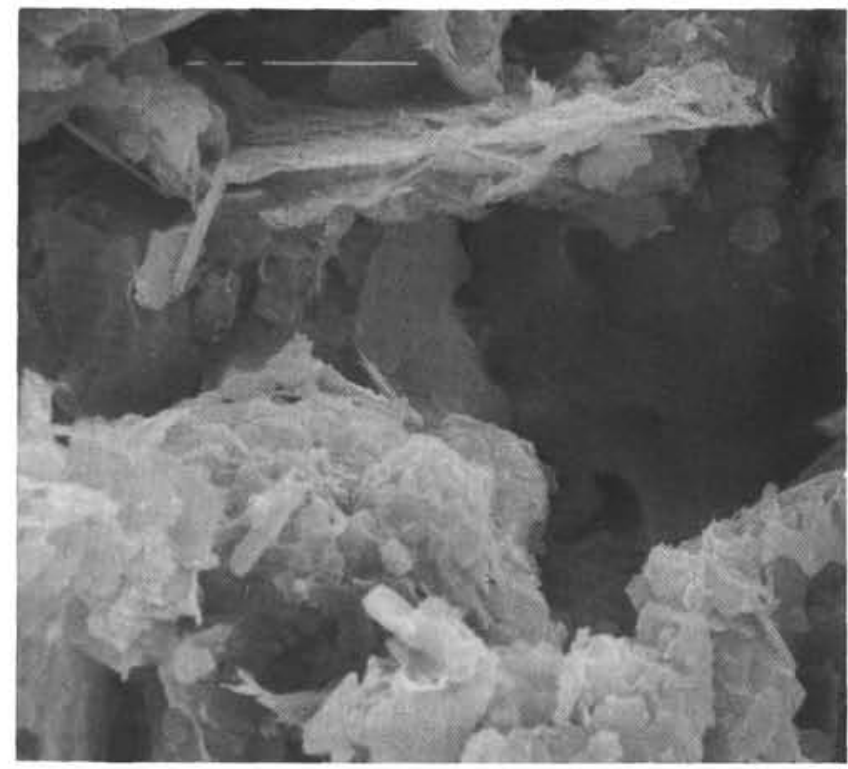

Figure 16. Mechanically dispersed chlorite and illite in trench sands lack the well-developed crystal structure characteristic of authigenic clays. (Hole 486, $11 \mathrm{~m}$ BSF, Quaternary; scale bar is $10 \mu \mathrm{m}$ ). 
The finer-grained sands are weakly consolidated by delicate films of illite and chlorite bridging the gaps between framework grains. These clays are most likely produced from the alteration of detrital biotite (Fig. 17).

Some dissolution and alteration features are common to detrital grains in both fine- and coarse-grained trench sands. These features include:

1) the development of dissolution canals in plagioclase and potash feldspars (Figs. 18 and 19);

2) the vacuolization and sericitization of plagioclase;

3 ) the growth of authigenic chlorite in dissolution voids in plagioclase and orthoclase;

4) the alteration and dissolution of detrital hornblende and pyroxene; and

$5)$ the micritization and dissolution of calcareous rock fragments and fossils.

The samples from Site 486 that were included in this study indicate that the diagenetic sequence begins with the dissolution of feldspars, hornblende, and pyroxene and the alteration of biotite to chlorite. Vacuolization and sericitization and plagioclase are accelerated with increasing depth of burial, as is the alteration of calcareous components. The abundance of matrix correlates with an increase in the percentage of rock fragments and is not simply a function of burial depth.

\section{DISCUSSION}

1. A summary of the features described in this report is presented in Table 2 . On the basis of textural and diagenetic similarities, sands and sandstones from the Middle America Trench and trench slope can be divided into three groups. The first category includes the upper slope calcite- and gypsum-cemented sandstones of Sites 489 and 493 . The second group includes the clay- and phyllosilicate-cemented sands from the accretionary zone (Site 488) and trench (Site 486) and the lower sequence of the midslope (Site 492). Moore (1979) described a similar distinction between calcite-cemented sandstones from the trench slope and phyllosilicate-cemented sandstones from a melange sequence on Nias Island. He did not, however, find an analog to the unconsolidated, tectonically fractured sands from the upper sequence of Site 492. Perhaps these sands define a transition zone between gypsum- and calcite-cemented sandstones of the upper slope and argillaceous sandstones of the lower slope and trench.

2. The relative order of cementation in the upper slope sands by clay skins and, subsequently, by calcite, is the reverse of the order described by Galloway (1974) from northeast Pacific sandstones. This reversal may reflect a difference in the origin of the clay. Galloway's Stage 2 clay coats and rims originated from the chemical alteration of volcanic rock fragments. The clay that formed skins on framework grains in the upper slope sands may have been introduced during bioturbation or may have settled from suspension. These differences in textures between the trench slope sands of this study and the forearc and back-arc sandstones of Galloway's (1974) study may be useful criteria for differentiating trench slope and arc-related basinal deposits in future studies.

3. In general, there is an increase in the abundance and diversity of accessory minerals in sediments with decreasing distance away from the trench. Selective postdepositional removal of these accessory minerals is suggested by the landward increase in the age of the sediments and the occurrence of dissolution features on detrital accessory minerals from the trench and lower slope.

4. Petrographic data are insufficient to resolve the question of whether or not the coarse-grained sediments at Sites 492 and 488 are uplifted trench deposits. Although similarities exist in the composition and in the production of pseudomatrix, deeper drilling and more detailed structural information are needed for definitive answers.

\section{ACKNOWLEDGMENTS}

I acknowledge the chief scientists and the entire Leg 66 staff for their cooperation and for the opportunity to contribute to the Initial Reports. Isotopic analyses of the calcareous sandstones were provided by Stephen Fisher at the University of Texas. Robert L. Folk and William E. Galloway reviewed the manuscript and made helpful sug. gestions for improvement. A very special thanks is extended to Earle F. McBride for reviewing the manuscript and for his valuable assistance during all phases of the research.

\section{REFERENCES}

Dickinson, W. R., 1970. Interpreting detrital modes of graywacke and arkose. J. Sediment. Petrol., 40:695-707.

Galloway, W. E., 1974. Deposition and diagenetic alteration of sandstone in northeast Pacific arc-related basins: Implications for graywacke genesis. Geol. Soc. Am. Bull., 85:379-390.

Hudson, J. D., 1977. Stable isotopes and limestone lithification. J. Geol. Soc. London, 133:637-660.

McBride, E. F., 1963. A classification of common sandstones. J. Sediment. Petrol., 33:664-669.

Moore, G. F., 1979. Petrography of subduction zone sandstones from Nias Island, Indonesia. J. Sediment. Petrol., 49:71-84.

Shipley, T. H., McMillen, K. J., Watkins, J. S., et al., 1980. Continental margin and lower slope structures of the Middle America Trench near Acapulco, Mexico. Mar. Geol., 35:65-82. 


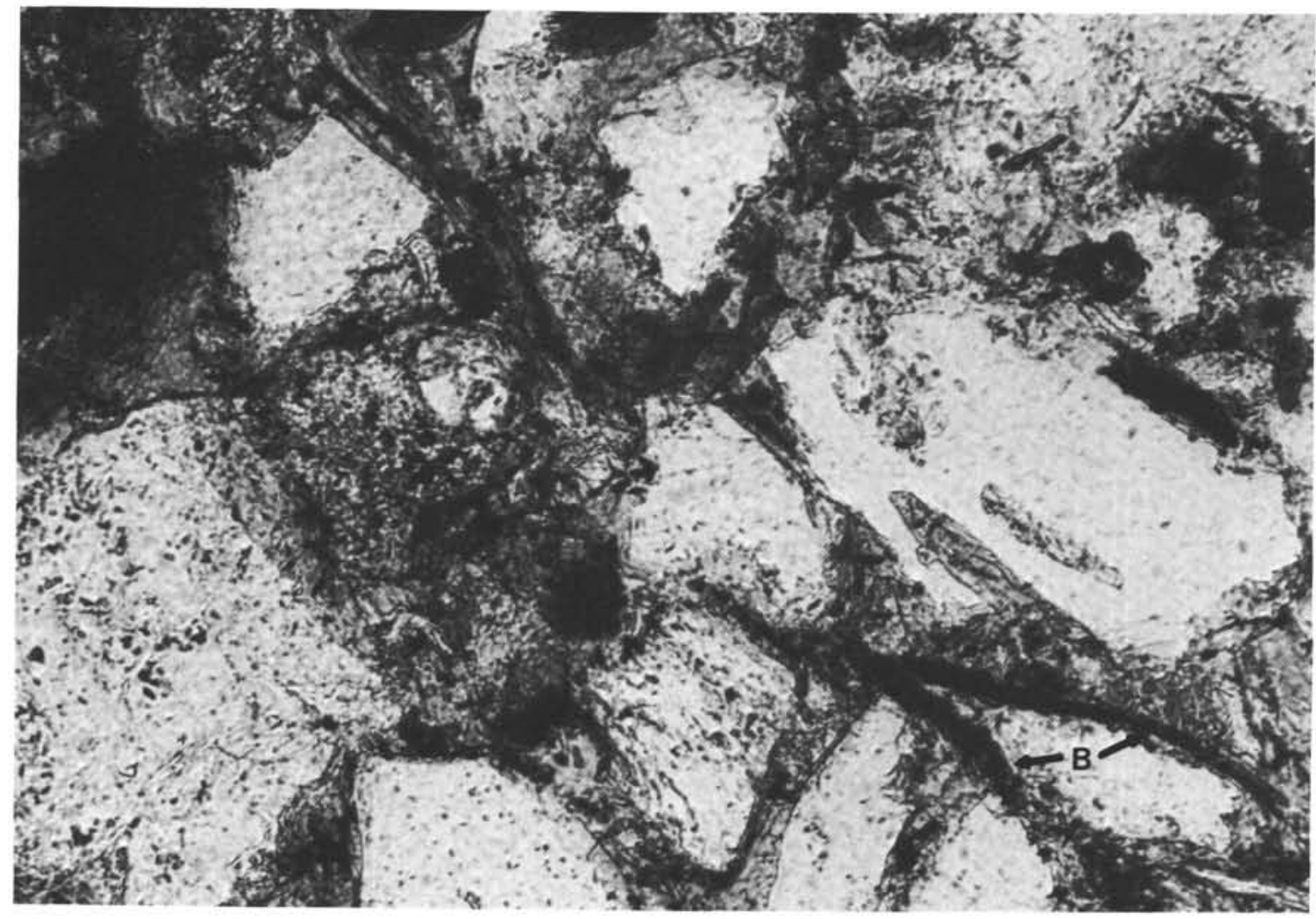

Figure 17. Origin of matrix in fine-grained trench sands-altered biotite (B) surrounding framework grains. (Hole 486, $16 \mathrm{~m}$ BSF, Quaternary; field of view is $0.55 \times 0.85 \mathrm{~mm}$.)

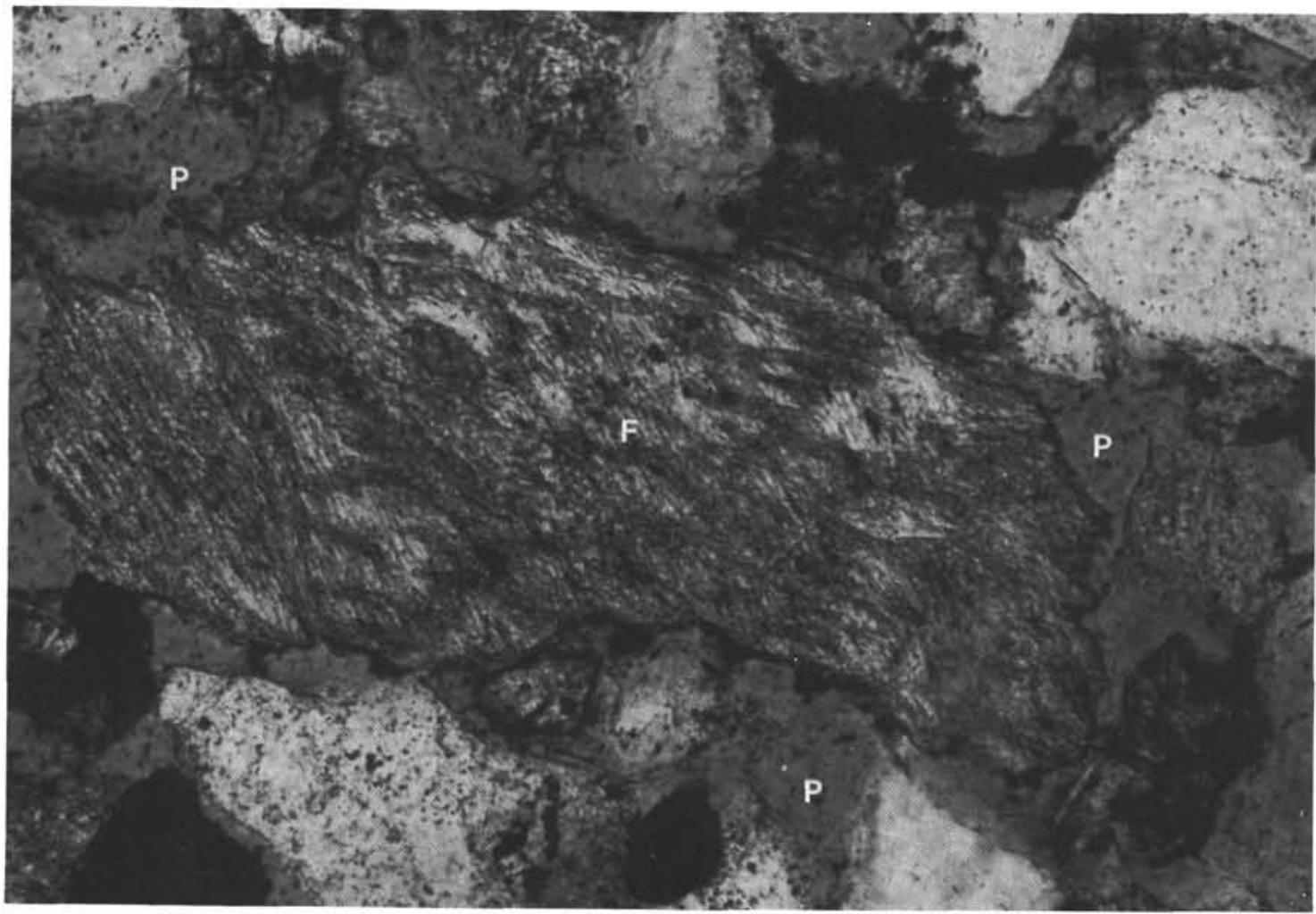

Figure 18. Partially dissolved orthoclase feldspar $(\mathrm{F})$ in porous trench sand; $\mathrm{P}=$ pore space. (Hole $486 \mathrm{~A}, 14.8 \mathrm{~m} \mathrm{BSF}$, Quaternary; field of view is $0.55 \times 0.85 \mathrm{~mm}$.) 


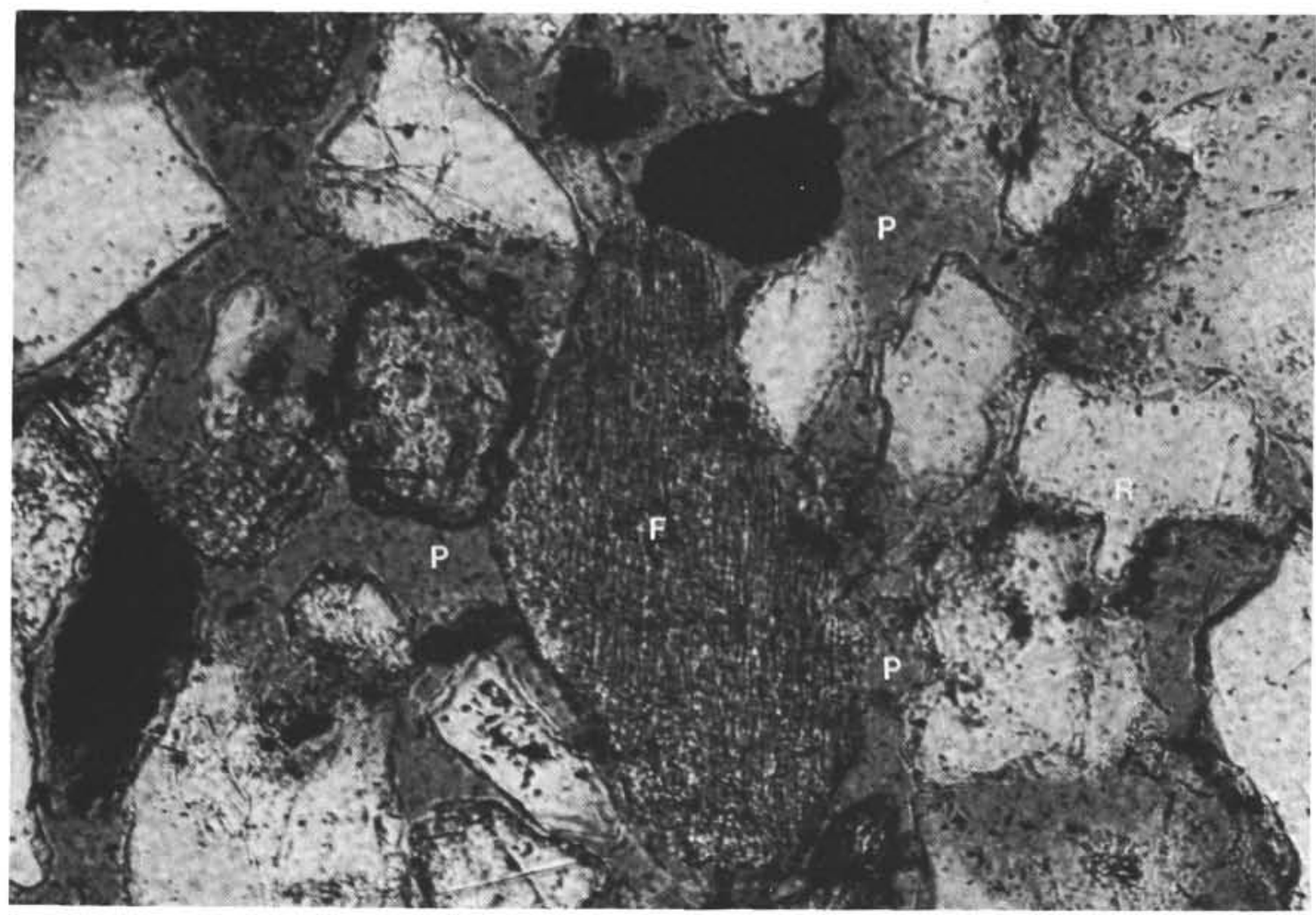

Figure 19. Partially dissolved detrital plagioclase feldspar $(\mathrm{F})$ in trench sand; $\mathrm{P}=$ pore space. (Hole $486 \mathrm{~A}, 14.8 \mathrm{~m} \mathrm{BSF}$, Quaternary; field of view is $0.55 \times 0.85 \mathrm{~mm}$.)

Table 2. Summary of diagenetic features in DSDP Leg 66 sands and sandstones.

\begin{tabular}{|c|c|c|c|c|c|c|}
\hline \multirow{2}{*}{\multicolumn{2}{|c|}{$\begin{array}{c}\text { Upper Slope } \\
\text { Site } 489\end{array}$}} & \multicolumn{3}{|c|}{ Mid- to Lower-Slope } & \multicolumn{2}{|c|}{ Trench Floor } \\
\hline & & Site 493 & Site 492 & Site 491 & Site 488 & Site 486 \\
\hline $\begin{array}{l}\text { Inter- } \\
\text { granular }\end{array}$ & $\begin{array}{l}\text { I clay skins } \\
2 \text { fibrous calcite } \\
3 \text { micritic to sparry } \\
\text { calcite cement }\end{array}$ & $\begin{array}{l}\text { Calcareous sandstones } \\
1 \text { clay skins } \\
2 \text { fibrous calcite } \\
\text { cement } \\
3 \text { siderite concretions } \\
4 \text { micritic to sparry } \\
\text { calcite cement } \\
\text { Gypsiferous sandstones } \\
\text { clay skins } \\
\text { pore-filling fibrous } \\
\text { gypsum }\end{array}$ & $\begin{array}{l}\text { Glauconitic sand } \\
1 \text { authigenic gypsum } \\
2 \text { deformation of } \\
\text { mud clasts } \\
\text { Mechanically dispersed } \\
\text { illite and chlorite }\end{array}$ & $\begin{array}{l}\text { Deformation of } \\
\text { mud clasts } \\
\text { Hematite coats }\end{array}$ & $\begin{array}{l}\text { Compacted mud } \\
\text { clasts }\end{array}$ & $\begin{array}{l}\text { Mechanically dis- } \\
\text { persed illite and } \\
\text { chlorite }\end{array}$ \\
\hline $\begin{array}{l}\text { Intra- } \\
\text { granular }\end{array}$ & $\begin{array}{l}\text { Chamber fillings } \\
1 \text { framboidal pyrite } \\
2 \text { sparry calcite } \\
\text { Detrital grains } \\
\text { replacement by } \\
\text { calcite } \\
\text { bloated biotite } \\
\text { recrystallized shell } \\
\text { fragments }\end{array}$ & $\begin{array}{l}\text { Chamber fillings } \\
\text { calcareous sandstone } \\
1 \text { framboidal pyrite } \\
2 \text { cristobalite } \\
3 \text { sparry calcite } \\
\text { gypsiferous } \\
\text { sandstones } \\
1 \text { pyrite and phillip- } \\
\text { site } \\
2 \text { gypsum } \\
3 \text { cristobalite } \\
\text { Detrital grains } \\
1 \text { vacuolization of } \\
\text { plagioclase } \\
2 \text { K-feldspar - clay } \\
3 \text { biotite - chlorite } \\
+ \text { pyrite } \\
4 \text { partial dissolution } \\
\text { of hornblende } \\
5 \text { micritization of } \\
\text { calcareous fossils } \\
6 \text { aragonite - calcite }\end{array}$ & $\begin{array}{l}\text { Fracturing of feld. } \\
\text { spars and hornblende } \\
\text { Biotite - chlorite } \\
\text { Kinked biotite } \\
\text { Corroded hornblende } \\
\text { Partial dissolution } \\
\text { of feldspars }\end{array}$ & $\begin{array}{l}\text { Vacuolization and } \\
\text { partial dissolution } \\
\text { of plagioclase } \\
\text { Bloating of } \\
\text { muscovite and } \\
\text { biotite } \\
\text { Fractured grains } \\
\text { Sericite and chlorite } \\
\text { growing in feld- } \\
\text { spar voids }\end{array}$ & $\begin{array}{l}\text { Partial dissolution } \\
\text { of hornblende, } \\
\text { pyroxene, feldspars } \\
\text { and microfossils } \\
\text { Kinked and } \\
\text { chloritized biotite }\end{array}$ & $\begin{array}{l}\text { Partial dissolution of } \\
\text { feldspars, calcareous } \\
\text { rock fragments, horn- } \\
\text { blende, pyroxene } \\
\text { Vacuolization and } \\
\text { sericitzed plagioclase } \\
\text { Chlorite in dissolution } \\
\text { voids in feldspars } \\
\text { Vacuolization and } \\
\text { sericitization of } \\
\text { plagioclase }\end{array}$ \\
\hline
\end{tabular}

